๑ Entomologica Fennica. 19 September 2003

\title{
Contribution to the fauna of Elachistidae (Lepidoptera) of the Southern Ural Mountains
}

\author{
Lauri Kaila, Kari Nupponen, Jari Junnilainen, Timo Nupponen, Jari-Pekka Kaitila \& \\ Vladimir Olschwang
}

Kaila, L., Nupponen, K., Junnilainen, J., Nupponen, T., Kaitila, J.-P. \& Olschwang, V. 2003: Contribution to the fauna of Elachistidae (Lepidoptera) of the Southern Ural Mountains. — Entomol. Fennica 14: 65-90.

The Elachistidae fauna of the southern Ural area, Russia, is outlined. A total of 51 species are listed, four of which remain unidentified to species level. Six species are described as new: Elachista (Aphelosetia) olschwangi Kaila sp. n., E. (A.) arduella Kaila sp. n., E. (A.) gibbera Kaila sp. n., E. (A.) chamaea Kaila sp. n., E. (A.) acutella Kaila sp. n. and E. (Elachista) devexella Kaila sp. n. Four species are reported for the first time from Europe and illustrated: Perittia sibirica Sinev, Elachista (Hemiprosopa) altaica (Sinev), E. (E.) megagnathos Sruoga and E. (E.) baikalica Kaila. The previously unknown female of E. megagnathos is described. Fourteen species are reported as new to Russia. Further illustrations and notes on some poorly known species are given.

Lauri Kaila, Finnish Museum of Natural History, Division of Entomology, P.O. Box 17, FIN-00014 University of Helsinki, Finland (E-mail lauri.kaila@helsinki.fi)

Kari Nupponen, Miniatontie 1 B 9, FIN-02360 Espoo, Finland

Jari Junnilainen, Mahlapolku 3, FIN-01730 Vantaa, Finland

Timo Nupponen, Riilahdentie 5 D 15, FIN-02360 Espoo, Finland

Jari-Pekka Kaitila, Kannuskuja 8 D 37, FIN-01200 Vantaa, Finland

Vladimir Olschwang, Nagornaja Street 11-32, RUS-620028 Ekaterinburg, Russia

Received 17 February 2003, accepted 10 April 2003

\section{Introduction}

The Ural Mountains form a $2000 \mathrm{~km}$ long natural border between Europe and Asia. The mountains almost reach the Caspian Sea in the south and the Arctic Ocean shore in the north. It is over 300 million years old (Olenev 1965) and a relatively low mountain range, the highest elevation in the southern part being $1640 \mathrm{~m}$ (a.s.l.). The biotopes at higher elevation are taiga forests with a few isolated mountain tundra habitats on the highest hilltops. In the region north of $55^{\circ} \mathrm{N}$ there are forest steppes, mixed forests and frequently small lakes, bogs and various kinds of wet meadows. The southeastern and southernmost parts of the Ural Mountains have been reduced to a foothill zone, gradually becoming lowland steppe without any clear border. In this region there exist sev- 


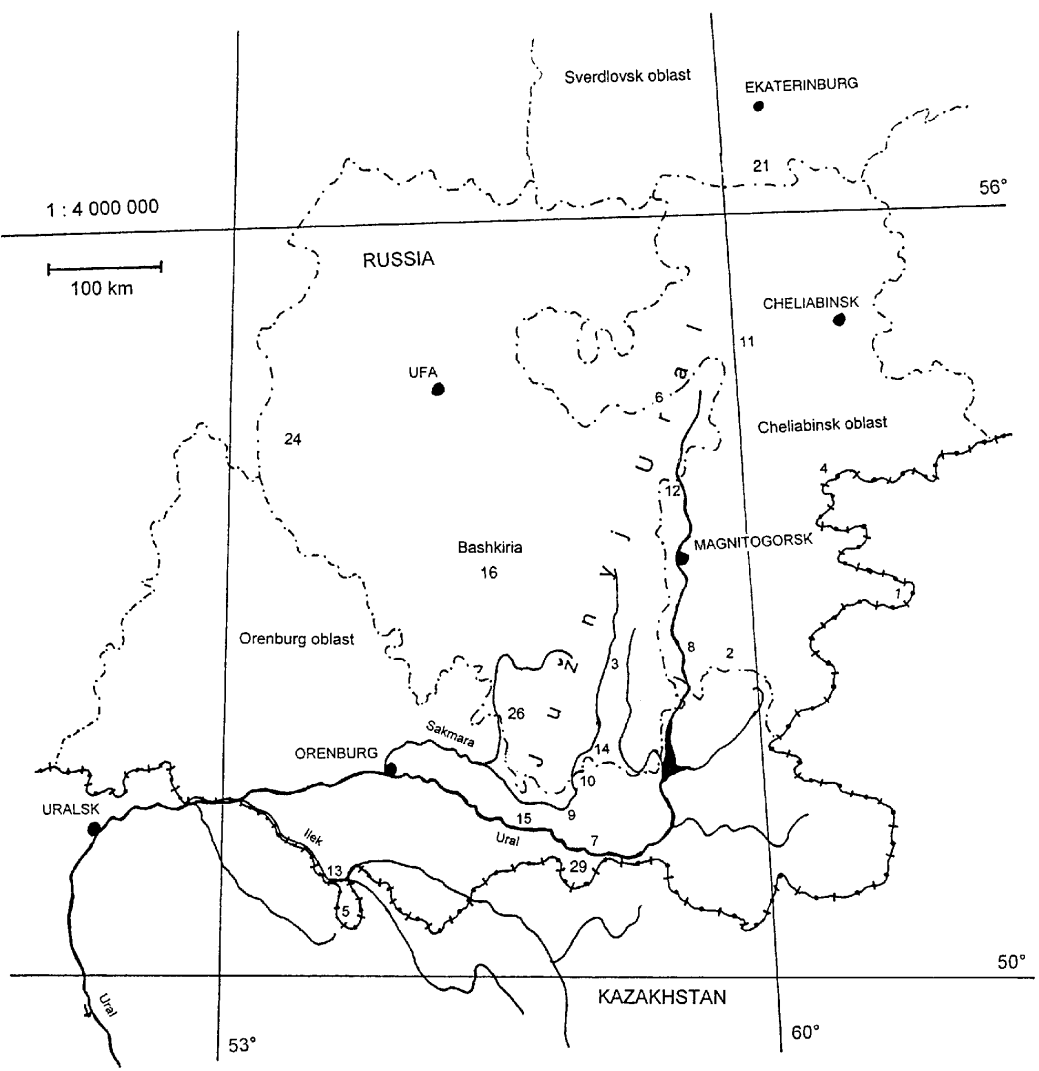

Fig. 1. Map of the study area. Numbers refer to the collecting sites of the material. eral rather large affluents of the river Ural (Utva, Ilek, Hobda, Kumak, Suundyk, Tamlyk, Sakmara, Salmych) increasing the diversity of nature. The lowland steppe belt continues up to Central Asia in the east. The western side of the southern Urals is mainly agricultural area with numerous oil wells as a distinctive mark.

The lepidopterology has a long history in the Southern Urals region, thanks to the work of Prof. E. Eversmann (1794-1860). In his works he outlined the Lepidoptera of the Volga-southern Ural area, and included records of a large number of larger Microlepidoptera as well. However, only a few representatives of the smaller sized moths, representatives of Elachistidae among them, were mentioned by him. The sole species of Elachistidae mentioned by him is Elachista galacticella (Eversmann) (as Oecophora galacticella) (Eversmann 1844). Later on, very little information has been published on the Elachistidae fauna of the region. These records include two further species only, Elachista fasciola Parenti by Sachkov (1995) and E. manni TraugottOlsen by Traugott-Olsen (1990a).
The recent collecting trips made by Finnish amateur entomologists have yielded a lot of new records from this area, including several species new to Europe and at least six undescribed species. To support the EU's Fauna Europaea programme aiming at mapping the distribution of all European animals, we here publish these records and earlier published records known to us. To our knowledge the earlier records of the area include no more than three species. In this paper we record the occurrence of 51 species of Elachistidae in the study area, including six species described here as new to science, and an additional four species reported for the first time from Europe. It should be noted that if the Ural River was used as the 'definite' border of Europe, some of the collecting sites would fall beyond the limits of Europe. However, it would not be sensible to divide southern Ural into two pieces in such a violent way, because the river Ural with its affluents widely meanders on both sides of the main flow forming a biogeographically compact region at the southern end of the Ural Mountains. 


\section{The investigated area, material and methods}

The investigated area is situated in Sverdlovsk, Cheliabinsk and Orenburg oblasts and Bashkiria in the southern Ural Mountains, between $50^{\circ} 40^{\prime} \mathrm{N}-56^{\circ} 30^{\prime} \mathrm{N}$ and $53^{\circ} 05^{\prime} \mathrm{E}-$ $62^{\circ} 06^{\prime} \mathrm{E}$. A few records from the lower Volga region are included in the list. The majority of collecting sites were located on the eastern-southern foothill region at low altitude. The habitats were mainly different kinds of steppes, but also taiga forests, alpine meadows and mountain tundra. The lowest locality was in the valley of the river Ilek, Novoiletzk (100 m a.s.1.) and the highest one the Iremel Mountain (1580 $\mathrm{m}$ a.s.1.). Most localities were lying at an elevation of $200-450 \mathrm{~m}$.

The present article is based on the material collected during 1996-2001 on 9 different expeditions. The dates, areas visited and collectors on each of the trips are as follows:

- 1: 13.-29.VI.1996; Cheliabinsk oblast, Bashkiria; K. Nupponen, J.-P. Kaitila, J. Junnilainen, M. Ahola.

— 2: 26.VI.-16.VII.1997; Cheliabinsk oblast; K. Nupponen, J.-P. Kaitila, J. Junnilainen, M. Ahola.

- 3: 25.V.-22.VI.1998; Orenburg oblast, Cheliabinsk oblast, Bashkiria; K. Nupponen, T. Nupponen, J. Junnilainen.

— 4: 11.-31.VII.1998; Orenburg oblast, Cheliabinsk oblast, Bashkiria; K. Nupponen.

- 5: 11.-20.V.1999; Orenburg oblast, Cheliabinsk oblast; K. Nupponen.

— 6: 13.-30.VI.1999; Orenburg oblast, Cheliabinsk oblast, Bashkiria; K. Nupponen, T. Nupponen.

— 7: 25.VII.-04.VIII.2000; Orenburg oblast, Cheliabinsk oblast, Bashkiria; T. Nupponen.

— 8: 29.-31.V.2001, 09.-28.VI.2001; Orenburg oblast, Cheliabinsk oblast, Bashkiria, Sverdlovsk oblast; K. Nupponen.

— 9: 12.-17.VI.2001: Orenburg oblast, Orenburgskii Natl. Pk., Burtinskij Steppe; J. Kullberg, M. Zalewski.

The material, comprising over 700 pinned specimens of Elachistidae, was collected both by artificial light at night and by sweeping and netting during daytime, especially at dusk. Identifications were made by Lauri Kaila. The collected material is generally deposited in the collections of the observers and the Finnish Museum of Natural History, University of Helsinki (ZMH).

\section{Collecting sites}

The collecting sites are briefly described below. Abbreviated variants of locality names are given in uppercase letters before each locality and used later in the species list. The italicised dates indicate daytime collecting only in the locality. The number given to each of the localities is connected with that on the map (Fig. 1). Colour photographs of some of the collecting sites are published by Nupponen \& Fibiger (2002).

- 1, AJAT RIVER: Cheliabinsk oblast, $53^{\circ} 02^{`} \mathrm{~N}$ 6206' $\mathrm{E}, 200 \mathrm{~m}$, Ajat river near Nikolaevka village. A rocky hill in a riverbank, surrounded by a moist place on a riverside and a large Artemisia steppe. 03.-05.VII.1997, 24.25.VII.1998, 04.-05.IX.2000.

- 2, ARKAIM: Cheliabinsk oblast, $52^{\circ} 39^{\prime} \mathrm{N}$ 59³4ㅌ, 350 m, Arkaim reserve near Amurskii village. A large reserve with different kinds of steppe habitats. 14.-19.VI.1996,06.-10.VII.1997, 22.-23.VII.1998, 17.V.1999, 15.-16.VI.1999.

- 3, BAJMAK: Bashkiria, 52 ${ }^{\circ} 40^{\prime} \mathrm{N} 58^{\circ} 34^{\prime} \mathrm{E}$, $450 \mathrm{~m}$, Bajmak $15 \mathrm{~km}$ E. Open foothill steppe locality. 17.-18.VI.1998.

- 4, BERLIN: Cheliabinsk oblast, $53^{\circ} 59^{\prime} \mathrm{N}$ $61^{\circ} 12^{\prime} \mathrm{E}, 250 \mathrm{~m}$, Troizkii reserve near Berlin village. A small, mainly grassland steppe surrounded by a bog and young forest. 30.VI.02.VII.1997.

- 5, CHALK HILLS: Orenburg oblast, 50 40 $45^{\prime} \mathrm{N}$ 5426-28’ E, 170-230 m, Pokrovka village $20 \mathrm{~km} \mathrm{~S}$, Schibendy valley. A dry, open, lowland Artemisia steppe with wet meadows along the small riverside. Whitish limestone rocks surround the flat valley, the vegetation being luxurious on northern slopes and very sparse but characteristic (e.g. Nanophyton erinaceum and Anabasis cretacea) on southern slopes. 03.-07.VI.1998, 17.18.VII.1998, 21.-24.VI.1999, 31.VII.01.VIII.2000,30.-31.VIII.2000, 10.-11.VI.2001.

- EKATERINBURG: Sverdlovsk oblast, Ekaterinburg city. 27.-28.VII.1998, 25.28.VI.2001.

- 21, EKATERINBURG BIOL.ST.: Sverdlovsk oblast, Ekaterinburg $50 \mathrm{~km} \mathrm{~S}$, near Dvurechensk village, biological station of Ural's university. Mixed forests, bogs and meadows. 20.-22.VI.1998.

- 6, IREMEL: Cheliabinsk oblast, $54^{\circ} 31-35^{\prime} \mathrm{N}$ 58 49-54`E, 900-1580 m. Iremel Mountain reserve. Taiga forest between $800-1300 \mathrm{~m}$, alpine meadows at $1300-1400 \mathrm{~m}$ and mountain tundra at the highest elevation over 1400 m. 23.-27.VI.1996, 11.-14.VII.1997, 25.-28.VI.1999, 16.-17.VI.2001. 


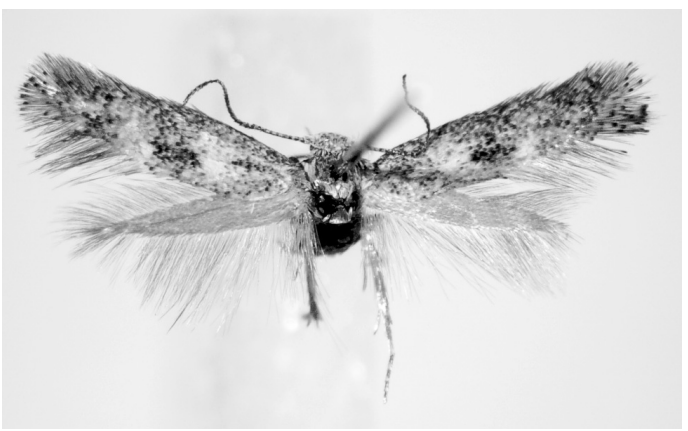

Fig. 2. Perittia sibirica Sinev, habitus of $0^{7}$ (Miass 13.VI.1996).

- 24, KANDRYKUL: Bashkiria, 54 $28^{\circ} \mathrm{N}$ $54^{\circ} 05^{\prime} \mathrm{E}, 200-250 \mathrm{~m}$, lake Kandrykul. Young forests and different kinds of meadows. 30.31.V.2001.

- 7, KIDRIASOVO: Orenburg oblast, $51^{\circ} 13^{\prime} \mathrm{N}$ $57^{\circ} 37^{\prime} \mathrm{E}, 350 \mathrm{~m}$, Mednogorsk $20 \mathrm{~km} \mathrm{~S}$, near Kidriasovo village. Open, partly gravelly foothill steppe with plenty of Caragana bushes in lower parts of the slopes and wet meadows between the hills. 28.-30.V.1998, 16.VI.1999.

- 8, KIZILSKOYE: Cheliabinsk oblast, $52^{\circ} 39^{\prime} \mathrm{N} 5^{\circ} 00^{\prime} \mathrm{E}, 300 \mathrm{~m}$, Kizilskoye $15 \mathrm{~km}$ $\mathrm{S}$, near Ural river. Dry, open Artemisia-Stipa steppe with rocky hills. 27.-28.V.1998, 18.V.1999, 26.VII.2000, 03.IX.2000.

- 9, KUVANDYK: Orenburg oblast, $51^{\circ} 26^{\prime} \mathrm{N}$ $57^{\circ} 26^{\prime} \mathrm{E}, 250 \mathrm{~m}$, Kuvandyk $12 \mathrm{~km}$ SE. A foothill region with different kinds of steppes and old Quercus-Populus-Betula forests on the top of the hills.13.-16.VI.1998, 19.21.VII.1998,15.V.1998,02.VIII.2000,02.IX.2000.

- 10, KUVANDYK II: Orenburg oblast, $51^{\circ} 37^{\prime} \mathrm{N} 57^{\circ} 34^{\prime} \mathrm{E}, 300 \mathrm{~m}$, Kuvandyk $30 \mathrm{~km}$ NE. Rocky hills and meadows, at the slopes some blackish coloured, hot, gravelly spots with sparse vegetation. 16.-17.VI.1998, 03. VIII.2000.

- 11, MIASS: Cheliabinsk oblast, $55^{\circ} 01^{\prime} \mathrm{N}$ $60^{\circ} 06^{\prime} \mathrm{E}, 350 \mathrm{~m}$, Miass, Ilmen State reserve. Forest steppes and old conifer forests. The records from Miasovo lake belonging to the same reserve (appr. $10 \mathrm{~km} \mathrm{NE}$ ) are included in Miass. 13.VI.1996, 28.-29.VI.1996, 26.29.VI.1997, 15.-16.VII.1997, 25.-26.V.1998, 19.-20.VI.1998, 11.V.1999, 18.-20.V.1999, 29.-30.VI.1999, 26.VIII.2000, 06.IX.2000,

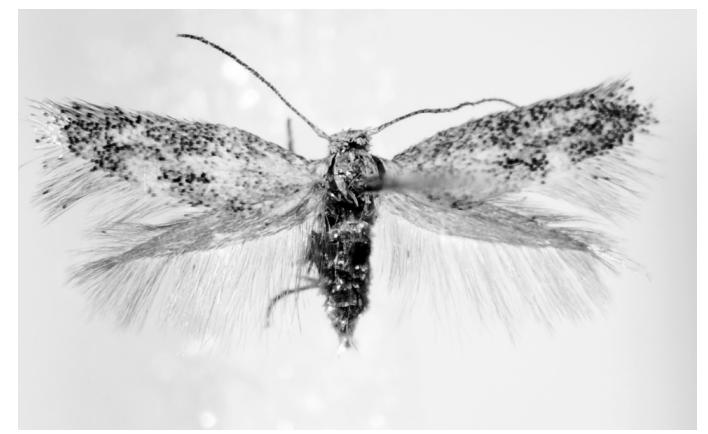

Fig. 3. Perittia sibirica Sinev, habitus of 9 (Kuvandyk 21.VII.1998).

29.-30.V.2001, 18.-21.VI.2001, 24.VI.2001; In addition, light trap collecting during 15.VI.24.VIII.1999, 25.VII.-05.IX.2000, 29.V.24.VI.2001.

- 12, MOSKOVO: Cheliabinsk oblast, 535ํN $59^{\circ} 03^{\prime} \mathrm{E}, 650 \mathrm{~m}$, near Moskovo village. Open, rocky foothill region with different kinds of steppes and wet meadows along the riverside. 22.-23.VI.1996, 10.-11.VII.1997, 26.V.1998, 18.VI.1998, 11.-13.VII.1998, 04.VIII.2000, 26.VIII.2000.

- 13, NOVOILETZK: Orenburg oblast, $50^{\circ} 59^{\prime} \mathrm{N} 54^{\circ} 17-22^{\prime} \mathrm{E}, 100 \mathrm{~m}$, Novoiletzk $8 \mathrm{~km}$ $\mathrm{E}$, Ilek river valley. Sand dune region with few Artemisia steppe spots, wet meadows and wetlands. 08.-09.VI.1998.

- 14, SAKMARA RIVER: Bashkiria, 51 ${ }^{\circ} 54^{\prime} \mathrm{N}$ 57 $43^{\prime} \mathrm{E}, 450 \mathrm{~m}$, Sakmara river near Jantyshevo village. Rocky slopes, forest steppes, meadows and mixed forests. 20.-21.VI.1996.

- 26, SULEIMANOVO: Bashkiria, $52^{\circ} 12^{`} \mathrm{~N}$ 56 $50^{\circ} \mathrm{E}, 400-500 \mathrm{~m}$, near Suleimanovo village. Rocky slopes, forest steppes, meadows and mixed forests. 14.-15.VI.2001.

- 15, VERBLJUSHKA: Orenburg oblast, $51^{\circ} 23^{\prime} \mathrm{N} \mathrm{56} 49^{\prime} \mathrm{E}, 130-340 \mathrm{~m}$, Donskoje village $6 \mathrm{~km}$ W, Mount Verbljushka. A $200 \mathrm{~m}$ high hill in the Ural River bank at the southern corner of the foothill region. The southern slope is extremely hot with more or less sparse vegetation. Artemisia steppe is present on the western slope and there is a quite luxuriant, rich flora on the northern slope. There are wet meadows and deciduous forest between the hill and the river banks. 30.V.-02.VI.1998, 10.-12.VI.1998, 14.-16.VII.1998, 12.- 


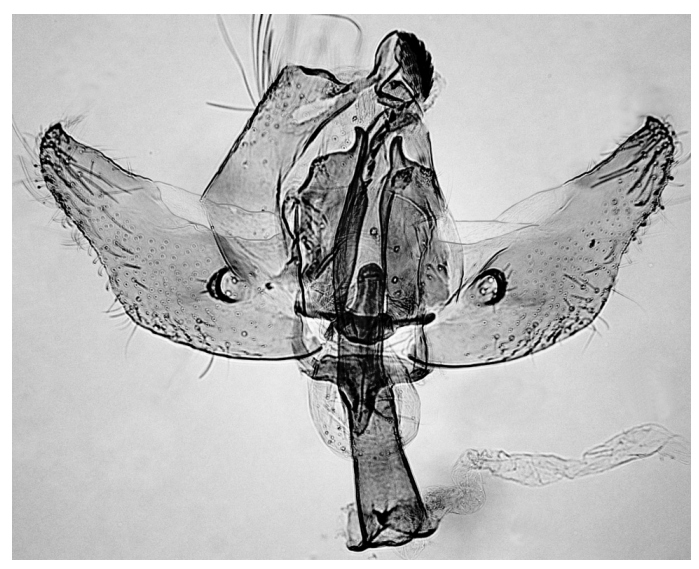

Fig. 4. Perittia sibirica Sinev, ơ genitalia (Miass 13.VI.1996, L. Kaila prep. n. 2523).

14.V.1999, 17.-19.VI.1999, 27.-29.VII.2000, 27.-28.VIII.2000.

- 16, ZIRGAN: Bashkiria, $53^{\circ} 12^{\prime} \mathrm{N} 56^{\circ} 00^{\prime} \mathrm{E}$, $400 \mathrm{~m}$, near Zirgan village. Forest steppes. 24.VI.1999.

- 17: Orenburg oblast, Orenburgskii Natl. Pk., Burtinskij Steppe. Open steppe habitats ranging from wet Phragmites stands to dry steppes with low vegetation. 12.-17.VI.2001.

\section{List of species}

The generic and subgeneric classification follows Kaila (1999a). The sequence of species of Elachista is based on grouping to species groups and complexes following the works of Traugott-Olsen \& Schmidt Nielsen (1977), Traugott-Olsen (1988), Traugott-Olsen (1990a), Kaila (1996), Kaila (1997), Kaila (1999b), Kaila \& Junnilainen (2002) and unpublished data of L. Kaila. The terminology follows Traugott-Olsen \& Schmidt Nielsen (1977) and Kaila (1999a). The dates and localities of records for each species are given, as well as further notes on some poorly known species.

\section{Perittia herrichiella (Herrich-Schäffer, 1855)}

Miass 27.VI.1997 1 O’ K. Nupponen \& J. Junnilainen leg.

Distribution. Widespread in Europe. Recorded also in Canada where it occurs probably due to an

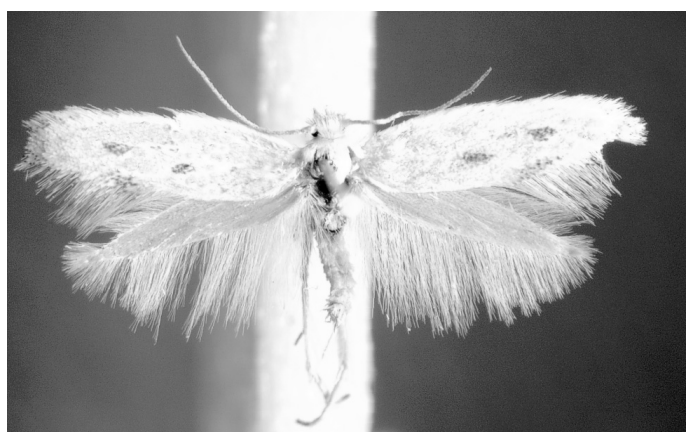

Fig. 5. Elachista altaica (Sinev), habitus of $0^{7}$ (Novoiletzk 8.VI.1998).

unintentional introduction (Kaila 1995). New to Russia.

\section{Perittia sibirica Sinev, 1992 (Figs. 2-4)}

Verbljushka 31.V.-2.VI.1998 3 ơ 3 @ J. Junnilainen leg., $10^{7} 3$ q T. \& K. Nupponen leg.; Chalk Hills 17.VII.1998 1 ㅇ K. Nupponen leg.; Kuvandyk 21.VII.1998 1 ㅇ K. Nupponen leg.; Miass 13.VI.1996 1 O’ K. Nupponen, J.-P. Kaitila, J. Junnilainen \& M. Ahola leg. (last specimen in ZMH), 27.VI.1997 2 ơ 1 ㅇ J.-P. Kaitila leg.

Distribution. The original description of Perittia sibirica was based on four specimens reared from Lonicera tatarica $\mathrm{L}$. from Irkutsk. No other records are known to us.

Remarks. New to Europe. The habitus of the male is illustrated in Fig. 2, that of the female in Fig. 3, and the male genitalia in Fig. 4.

\section{Elachista (Hemiprosopa) altaica (Sinev, 1998)} (Figs. 5 and 6)

Novoiletzk 8.VI.1998 3 O’ J. Junnilainen leg., 9.VI.1998 3 ơ T. \& K. Nupponen leg.

Distribution. The original description of $E$. altaica (Sinev) was based on one specimen from Altai Mts. In addition, there are specimens collected from Russia: Tuva Rep.: Ust-Ujuk 1998 J. Jalava \& J. Kullberg leg. (ZMH). No other records are known to us.

Remarks. New to Europe. The specimens were found at a saline wetland. The habitus of $0^{7}$ is illustrated in Fig. 5, and the male genitalia in Fig. 6. 


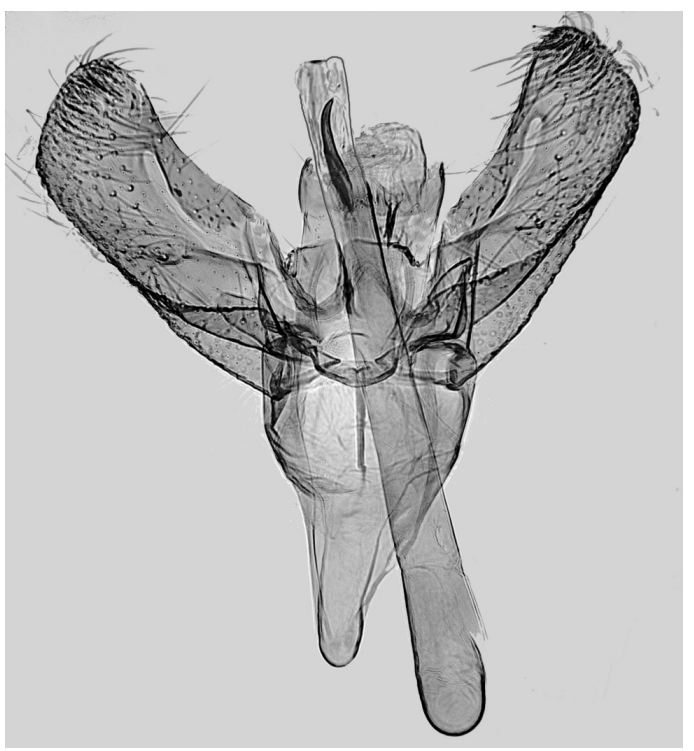

Fig. 6. Elachista altaica (Sinev), ơ genitalia (Russia: Tuva rep. $52^{\circ} 04^{\prime} \mathrm{N} 94^{\circ} 22^{\prime} \mathrm{E}, 670 \mathrm{~m}$, Ust-Ujuk 3.5.VI.1995 Jalava \& Kullberg leg., L. Kaila prep. n. 1762).

\section{Elachista (Dibrachia) kalki Parenti, 1978}

Kizilskoye 27.V.1998 6 O' J. Junnilainen leg., 30 O’ T. \& K. Nupponen leg.; Moskovo 26.V.1998 1 Ơ J. Junnilainen leg.; Kidriasovo 28.-29.V.1998 13 O' J. Junnilainen leg., 2 O' T. \& K. Nupponen leg.; Verbljushka 13.V.1999 3 O’ K. Nupponen leg.; Berlin 30.VI.1997 1 O$^{7}$ K. Nupponen \& J. Junnilainen leg.

Distribution. Central and eastern Europe, Kazakhstan, Russia: Tuva Rep.

\section{Elachista (Aphelosetia) olschwangi Kaila sp. n. (Figs. 7-10)}

Holotype $0^{7}$ : Russia, S. Ural, Cheliabinsk distr. $53^{\circ} 57^{\prime} \mathrm{N} 59^{\circ} 03^{\prime} \mathrm{E}, 650 \mathrm{~m}$, near Moskovo village 22.VI.1996 K. Nupponen, J.-P. Kaitila, J. Junnilainen \& M. Ahola leg. L. Kaila prep. n. 3312 (in coll. ZMH).

Paratypes (67 $0^{7} 4$ O): $100^{7}$ with the same label data as in the holotype; Cheliabinsk distr. near Moskovo village 10.VII.1997 1 O' K. Nupponen \& J. Junnilainen leg.; Cheliabinsk oblast, 52 $2^{\circ} 9^{\prime} \mathrm{N}$ 59³4ㅌ, 350 m, Arkaim reserve near Amurskii

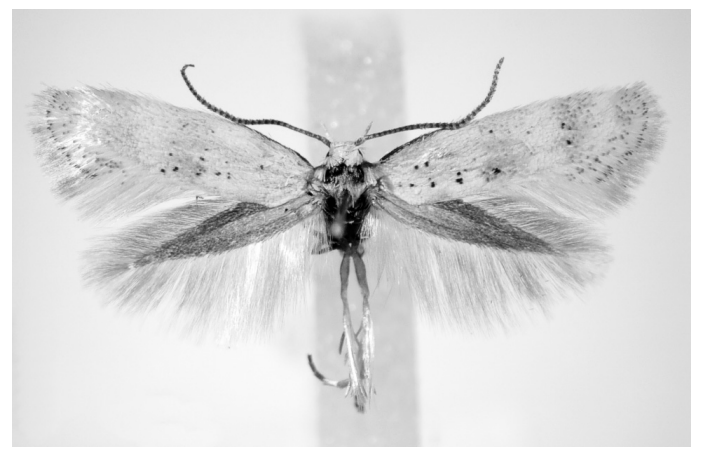

Fig. 7. Elachista olschwangi sp. n. holotype o’.

village 14.-19.VI.19964 0’ 1 O ; Cheliabinsk distr.,

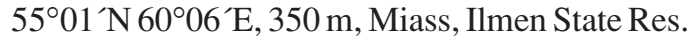
28.VI.1996 2 ơ K. Nupponen, J.-P. Kaitila, J.

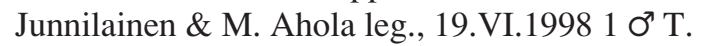
$\&$ K. Nupponen leg.; Orenburg distr. 51 $23^{\prime} \mathrm{N}$ 56ํํ르, 130-340 m 6 km W Donskoje Village, Mt. Verbljushka 10.-12.VI.1998 10 o’ 1 ㅇ J. Junnilainen leg., 30 V.1998 3 ơ, 1. VI.1 ơ,

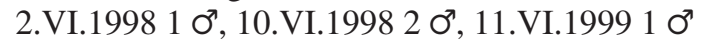
1 ㅇ, 17.VI.1999 1 ơ 1 ㅇ, 19.VI.1998 1 ơ T. \& K. Nupponen leg.; Bashkiria, 51 ${ }^{\circ} 54^{\prime}$ N $57^{\circ} 43^{\prime} \mathrm{E}, 450$ $\mathrm{m}$, Sakmara river, Jantyshevo village 21.VI.1996 $28 \sigma^{7}$ K. Nupponen, J.-P. Kaitila, J. Junnilainen \& M. Ahola leg.; Astrahan distr. nr. Bogdo village, Baskunzak salt lake 4.VI.2001 1 O' K. Nupponen leg.

Diagnosis. Elachista olschwangi sp. n. is similar to E. pollinariella Zeller, E. dumosa Parenti, E. nevadensis Parenti and especially E. gormella Nielsen \& Traugott-Olsen (cf. Traugott-Olsen \& Schmidt Nielsen (1977), Parenti (1978), Parenti (1981) and Nielsen \& Traugott-Olsen (1987)). From E. pollinariella and E. dumosa it is readily separated by its smaller and deeply incised uncus lobes, and the female papillae anales that are not sclerotised in E. olschwangi, but are sclerotised and expanded in these two species. The shape of juxta lobes is quite different in E. olschwangi from E. nevadensis as being much longer and not laterally produced in E. olschwangi. From E. gormella E. olschwangi differs externally by its pale yellowish forewing colour, E. gormella being darker brownish; in the male genitalia as having broader valva and aedeagus than E. gormella and in the shape of juxta lobes which are medially distinctly convex in E. olschwangi, but nearly straight in $E$. 


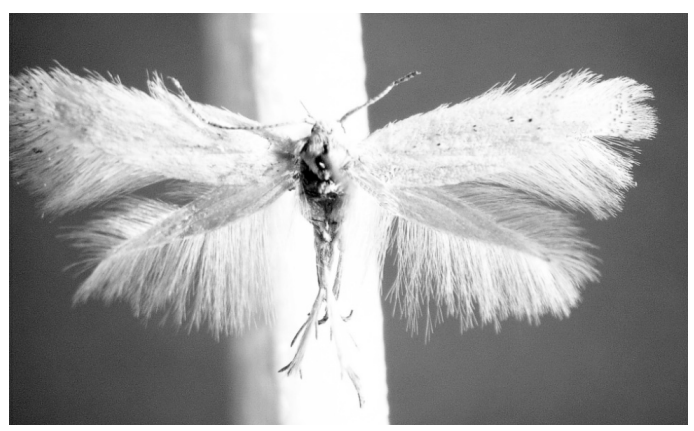

Fig. 8. Elachista olschwangisp. n. paratype ㅇ.

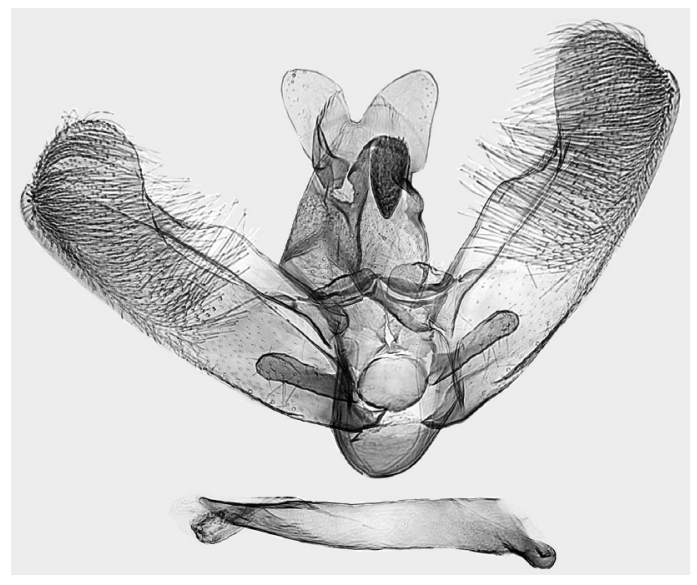

Fig. 9. Elachista olschwangi sp. n. ơ genitalia (holotype, L. Kaila prep. n. 3312).

gormella; in the female by the signum which is large, boomerang-shaped in E. olschwangi, smaller and nearly rounded in E. gormella. Externally $E$. olschwangi also resembles $E$. subocellea which occurs at the same area. $E$. subocellea however has strong orange transverse fasciae across forewing. Their male genitalia are readily separated by the broader valva and more rounded uncus of $E$. olschwangi as compared to E. subocellea. The vesica of E. subocellea contains a large horn-shaped cornutus that is lacking in E. olschwangi. The female genitalia of these species are easiest distinguished by the signum which is present as large and boomerang-shaped in E. olschwangi, but is absent in E. subocellea.

Description of $\sigma^{\prime}$. Wing span 10-11.4 mm. Labial palpus 1.2 times the diameter of head, creamy white, second segment variably suffused with grey below. Head, neck tuft, tegula and tho-

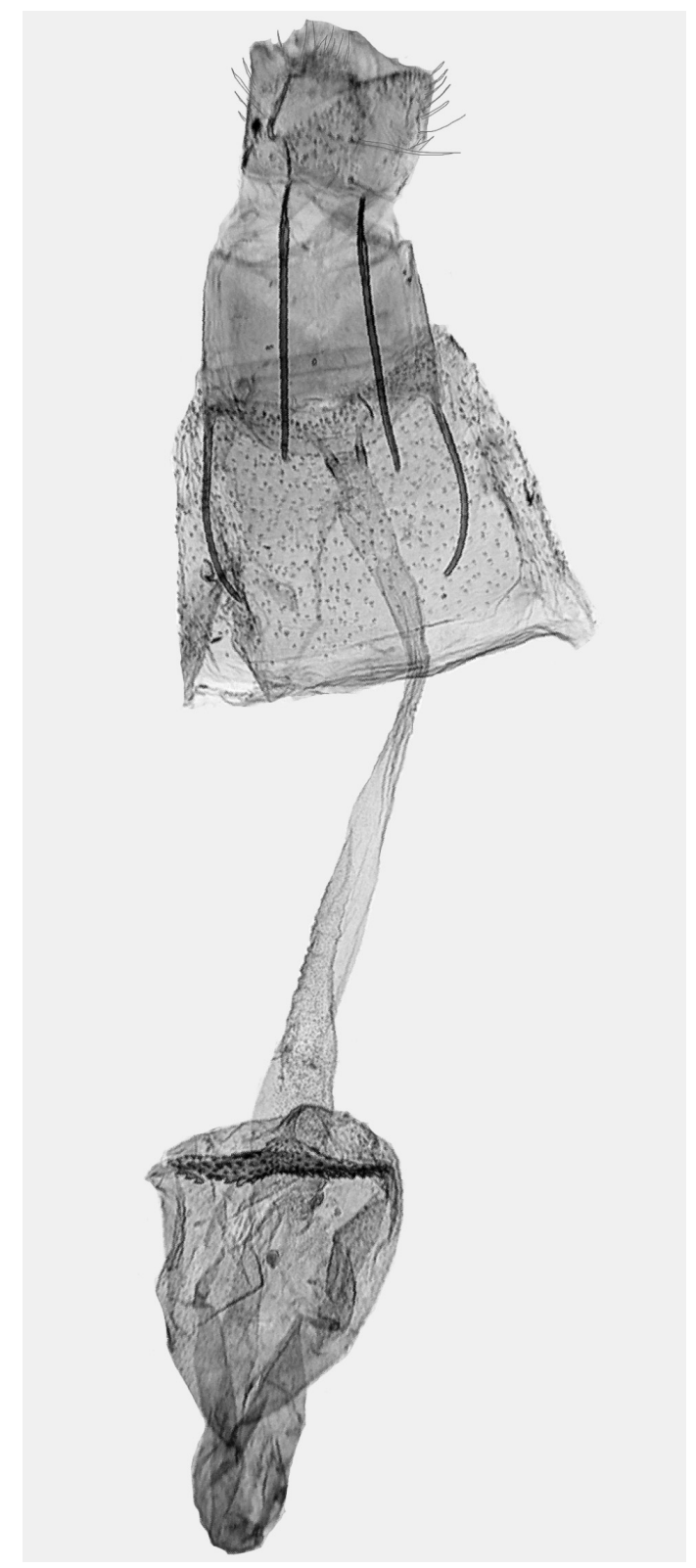

Fig. 10. Elachista olschwangi sp. n. O genitalia (paratype, L. Kaila prep. n. 3317).

rax creamy white. Scape of antenna suffused with grey, flagellum grey, annulated with somewhat paler rings. Foreleg dark grey, tibius and tarsal articles distally white; midleg leaden grey, tibius and tarsal articles distally white; hindleg inwardly ochreous, outwardly pale grey, tibius and tarsal articles distally ochreous white. Abdomen dorsally 
shiny grey, segments distally paler, ventrally shiny pale grey. Forewing ground colour creamy white, sparsely scattered with raised dark grey tipped scales that sometimes form indistinct elongate patch between fold and dorsal margin in the middle of wing; across forewing four indistinctly delimited transverse ochreous brown fasciae: one at basal $1 / 5$, one in the middle, one at distal $1 / 3$, and one narrowly along termen; shorter fringe scales distally brown forming brown double fringe line; fringe scales brown except at apex creamy white. Underside of forewing dark grey, fringe scales ochreous, distally brown. Hindwing dark grey above with ochreous grey fringe scales, below costal half dark grey, dorsal half pale grey; fringe scales ochreous grey.

Female otherwise as male but flagellum of antenna thinner and more strongly annulated; forewing pale creamy white with very indistinct brownish transverse fasciae, and scattered with fewer raised brown-tipped scales.

Male genitalia: Uncus lobes slightly longer than wide, somewhat tapered towards broadly rounded apex, medially separated by deep indentation. Mesial knob of gnathos basally broad, three times longer than wide, basally nearly parallelsided, distally tapered to pointed apex. Median plate of juxta rounded, evenly concave; juxta lobes longer than wide, mesial margin straight, joining distal margin without an angle; distal margin weakly convex, with a row of setae; lateral margin sclerotised, almost straight. Digitate process tongue-shaped, parallel-sided, distally blunt, length $1 / 2$ of the length of valva. Valva broad; basal and distal fold of costa meet at half of the length of valva, costa medially convex; sacculus straight, meeting cucullus in a somewhat obtuse angle and with a small distal tooth; cucullus large, produced towards costa. Aedeagus 4/5 length of valva; broadest basally, gradually tapered towards pointed apex; basal opening dorsoposteriorly directed, caecum a blunt sac. Distal opening extended to $3 / 5$ length of aedeagus; vesica with weakly sclerotised wrinkled sac and a group of minute spines.

Female genitalia: Papillae anales broad triangular, ventrally joined by $\mathrm{Y}$-shaped sclerotisation. Apophyses posteriores straight, 1.5 times longer than the somewhat bent apophyses anteriores. Ostium bursae nearly rounded without sclerotised reinforcements, antrum absent; colliculum short, ductus seminalis incepted anterior to it. Ductus bursae about three times longer than apophyses posteriores, membranous and without internal sclerotisations, anteriorly gradually broadened and laterally covered with minute granules; abruptly inserted to the oval-shaped corpus bursae. Median part of corpus bursae broadly covered with minute internal spines; signum as large as width of corpus bursae, dentate, medially widened to posterior direction.

\section{Elachista (Aphelosetia) adscitella Stainton, 1851}

Elachista revinctella auct., nec Zeller, 1850

Moskovo 10.VII.1997 1 Ơ' K. Nupponen \& J. Junnilainen leg.

Distribution. Transpalaearctic.

Remarks. E. adscitella was erroneously called E. revinctella Zeller in Traugott-Olsen \& Schmidt Nielsen (1977), and subsequently in e.g. Falkovich (1990), Kaila (1992) and Sinev \& Sruoga (1997). The identity of these species was corrected by Parenti (1992).

\section{Elachista (Aphelosetia) subalbidella Schläger, 1847}

Arkaim 15.VI.1996 1 O K. Nupponen, J.-P. Kaitila, J. Junnilainen \& M. Ahola leg.; Iremel, 900-1300 m, 24.VI.1996 1 O’ K. Nupponen, J.-P. Kaitila, J. Junnilainen \& M. Ahola leg., 800 m, 25.VI.1999 3 ơ 1 우 T. \& K. Nupponen leg.

Distribution. Holarctic (Kaila 1997).

\section{Elachista (Aphelosetia) obliquella Stainton, 1854}

Elachista megerlella auct. nec Hübner, 1810

Verbljushka 10.VI.1998 1 ○’ T. \& K. Nupponen leg.

Distribution. Europe.

Remarks. New to Russia. The name megerlella was considered to belong to Adelidae by Kozlov $\&$ Kaila (2002). Therefore the name obliquella Stainton, 1854 is now the oldest name available for this species. 
Elachista (Aphelosetia) cingillella (HerrichSchäffer, 1855)

Verbljushka 12.VI.1998 1 우 T. \& K. Nupponen leg.

Distribution. Central and northern Europe.

Remarks. The identity of this species has been largely misunderstood in the literature. For a review of this species complex, see Kaila \& Junnilainen (2002).

\section{Elachista (Aphelosetia) fasciola Parenti, 1983}

Arkaim 18.VI.1996 2 ơ K. Nupponen, J.-P. Kaitila, J. Junnilainen \& M. Ahola leg.; Miass 26.VI.1997 1 O', 27.-28.VI.1997 2 O’ K. Nupponen \& J. Junnilainen leg.; Iremel, 800 m, 25.VI.1999 1 O' T. \& K. Nupponen leg.; Verbljushka 31.V.1998 3 o' 1 o, 2.VI.1998 4 O' 4 o , 12.VI.1998 1 ơ, 16.VII.1998 8 O' T. \& K. Nupponen leg., 10.-12.VI.1998 1 ơ 2 우 J. Junnilainen leg., 12.V.1999 1 O’ K. Nupponen leg.; Kuvandyk

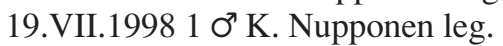

Distribution. Transpalaearctic, from Eastern Europe to Urals, Russian Far East and Japan.

Remarks. The identification of this species is treated by Kaila \& Junnilainen (2002). Many of the specimens were collected at afternoon.

\section{Elachista (Aphelosetia) gangabella Zeller, 1850}

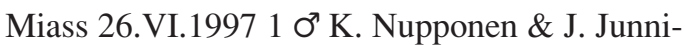
lainen leg., 27.VI.1997 1 \& J.-P. Kaitila leg.; 28.VI.1997 4 우 K. Nupponen \& J. Junnilainen leg. 28.VI.1999 1 O' T. \& K. Nupponen leg.;

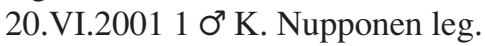

Distribution. Europe. Reported from Jaroslav oblast by Klepikov (2001).

Elachista (Aphelosetia) hedemanni Rebel, 1899

Verbljushka 30.V.1998 3 ơ 2 우, 1.VI.1998 2 0’ 1 O T. \&. K. Nupponen leg., 12.-14.V.1999 21 O' 3 O K. Nupponen leg.; Kidriasovo 28.-29.V.1998 1 $\mathrm{O}^{7}$ J. Junnilainen leg.; Moskovo 26.V.1998 10 0 T. \& K. Nupponen leg., 4 O' J. Junnilainen leg.; Chalk Hills 3.-6.VI.1998 4 O' T. \& K. Nupponen leg., 2 O7 J. Junnilainen leg.; Kizilskoye 27.V.1998 $10^{7}$ T. \& K. Nupponen leg.; Kuvandyk II 16.VI.1998 1 O’ T. \& K. Nupponen leg.; Arkaim 15.VI.1996 1 ○’ K. Nupponen, J.-P. Kaitila, J. Junnilainen \& M. Ahola leg.

Distribution. C. and S. Europe, Russia (Tuva Rep., unpublished material in ZMH). Seemingly Transpalaearctic in steppe regions.

Remarks. New to Russia.

\section{Elachista (Aphelosetia) szocsi Parenti, 1978}

Elachista manca Falkovich, 1986

Bajmak 17.VI.1998 1 Ơ' T. \& K. Nupponen leg.; Arkaim 15.VI.1996 9 O’ K. Nupponen, J.-P. Kaitila, J. Junnilainen \& M. Ahola leg.; Miass 28.VI.1996 1 O’ K. Nupponen, J.-P. Kaitila, J. Junnilainen \& M. Ahola leg., 27.VI.1997 1 O’ K. Nupponen \& J. Junnilainen leg., 19.VI.1998 1 O' T. \& K. Nupponen leg.; Kuvandyk II 16.VI.1998 2 O' T. \& K. Nupponen leg.; Kidriasovo 29.V.1998 1 O’ T. \& K. Nupponen leg.; Verbljushka 11.VI.1998 1 ㅇ T. \& K. Nupponen leg.

Distribution. Hungary (Parenti 1978), southern Siberia (Kaila 1992), Uzbekistan (Falkovich 1986).

\section{Elachista (Aphelosetia) heringi Rebel, 1899}

Zirgan 24.VI.1999 1 Ơ T. \& K. Nupponen leg.;

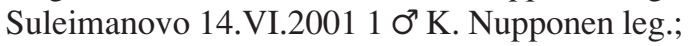
Chalk Hills 3.-7.VI.1998 11 O' J. Junnilainen leg., 10 O’ 2 우 T. \& K. Nupponen leg.; Arkaim 15.18.VI.1996 8 ơ 1 우 K. Nupponen, J.-P. Kaitila, J. Junnilainen \& M. Ahola leg., 15.VI.1999 1 O’ 2 우 T. \& K. Nupponen leg.; Verbljushka 30.V.-1.VI. 19987 ơ 1 ㅇ, 11.VI.1998 1 0', 18.VI.1998 1 우 T. \& K. Nupponen leg.; Miass 19.VI.1998 1 O' T. \& K. Nupponen leg.; Kidriasovo 28.V.1998 11 o", 16.VI.1999 1 Ơ T. \& K. Nupponen leg.; Moskovo 18.VI.1998 2 ㅇ T. \& K. Nupponen leg.; Kuvandyk II 16.VI.1998 1 o' T. \& K. Nupponen leg.; Orenburg distr. Orenburgskij Nat. Pk. 12.17.VI.2001 1 ○’ 1 우 J. Kullberg \& M. Zalewski leg.; Volgograd distr., 20 km SW Olhovka village 1.VI.2001 $10^{7} 1$ 우 K. Nupponen leg.

Distribution. Transpalaearctic in steppe regions. 
Elachista (Aphelosetia) subocellea (Stephens, 1834)

Miass 28.VI.1996 1 O' K. Nupponen, J.-P. Kaitila, J. Junnilainen \& M. Ahola leg., 26.-27.VI.1997 3 O’ 1 ㅇ J.-P. Kaitila leg., 26.VI.1997 2 Ơ 1 ㅇ K. Nupponen \& J. Junnilainen leg., 19.VI.2001 1 O", 24.VI.2001 1 우 K. Nupponen leg.

Distribution. Europe.

Remarks. E. subocellea belongs to the E. collitella complex as defined by Traugott-Olsen (1996). The taxonomy of this complex is unsettled, and in need of examination of good samples throughout the distribution ranges of the taxa involved. This is because both the male and the female genitalia of, e.g., E. subocellea display an exceptionally high level of variation in the structures of both male and female genitalia. The differences between specimens originating from one population can be so substantial that one would suspect the presence of more species unless a large series was examined showing the nature of the variation. There are, however, also seemingly constant differences between some populations suggesting that more than one species could indeed be involved in Europe. The specimens from S. Urals slightly differ from western and southern European specimens examined by us. As long as the possible significance of these minor differences is unknown we prefer considering the population of southern Urals to belong to E. subocellea. New to Russia.

\section{Elachista (Aphelosetia) bedellella Sircom, 1848}

Arkaim 15.VI.1999 1 Ơ T. \& K. Nupponen leg.; Chalk Hills 3.-6.VI.1998 5 우 7 우 T. \& K. Nupponen leg., 11.VI.2001 $10^{7}$ K. Nupponen leg.; Kidriasovo 28.-29.V.1998 $20^{>} 2$ \& J. Junnilainen leg.; Kuvandyk 14.VI.1998 1 O 1 1 ㅇ T. \& K. Nupponen leg.; Orenburg distr. Orenburgskij Nat. Pk. 12.-17.VI.2001 1 O' J. Kullberg \& M. Zalewski leg.; Suleimanovo 14.VI.2001 1 O' 2 우 K. Nupponen leg.; Verbljushka 10.VI.1998 2 O’ 2 \% T. \& K. Nupponen leg.

Distribution. The distribution of E. bedellella is somewhat unclear due to confusion with $E$. lugdunensis Frey (= E. coeneni Traugott-Olsen). These species, if distinct, seem to be best characterised by their forewing pattern. The forewings of E. bedellella are brownish grey with distinctive white transverse fascia, costal and tornal spots, while those of E. lugdunensis are blurred whitish or pale greyish-brownish grey with indistinct pattern. The taxonomic status of the populations externally resembling E. lugdunensis outside Europe is unclear. The 'typical' E. bedellella is distributed to central and southern Europe.

Remarks. New to Russia.

\section{Elachista (Aphelosetia) pullicomella Zeller,} 1839

Ekaterinburg biol. st. 20.VI.1998 1 O T. \& K. Nupponen leg.; Miass 26.-28.VI.1997 27 O' 13 우 K. Nupponen \& J. Junnilainen leg., 26.VI.1997 5 O’ 1 \% J.-P. Kaitila leg., 28.VI.1999 1 Ơ T. \& K.

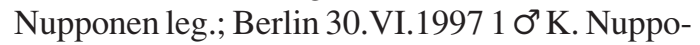
nen \& J. Junnilainen leg.

Distribution. Europe, central Asia (Kaila 1992).

\section{Elachista (Aphelosetia) littoricola Le Marchand, 1938}

Arkaim 22.VII.1998 1 Ơ K. Nupponen leg.; Kuvandyk 20.VII.1998 1 ㅇ K. Nupponen leg.; Verbljushka 11.VI.1998 1 , 12.VI.1998 1 O’ T. \& K. Nupponen leg.

Distribution. Europe.

Remarks. New to Russia.

Elachista (Aphelosetia) squamosella (Duponchel, 1843)

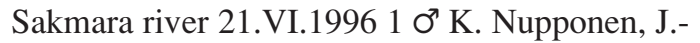
P. Kaitila, J. Junnilainen \& M. Ahola leg.; Verbljushka 14.-15.VII.1998 2 O’ K. Nupponen leg.

Distribution. Southern and central Europe, Ukraine.

Remarks. New to Russia.

Elachista (Aphelosetia) rudectella Stainton, 1851

Arkaim 9.VII.1997 1 O' K. Nupponen \& J. Junnilainen leg.; Kidriasovo 16.VI.1999 1 Ơ T. \& K. 


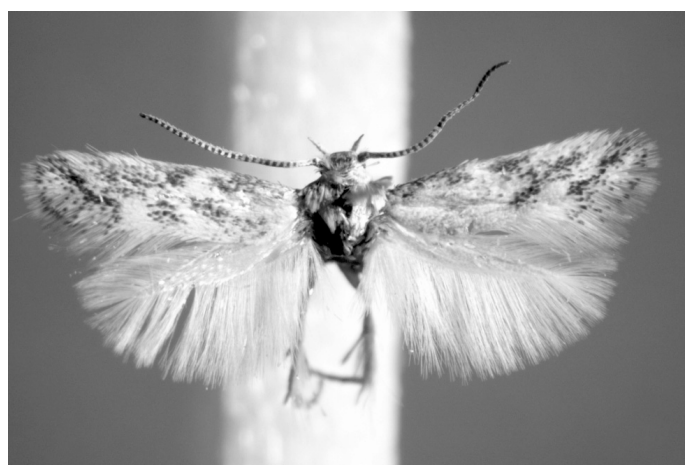

Fig. 11. Elachista arduella sp. n. holotype o".

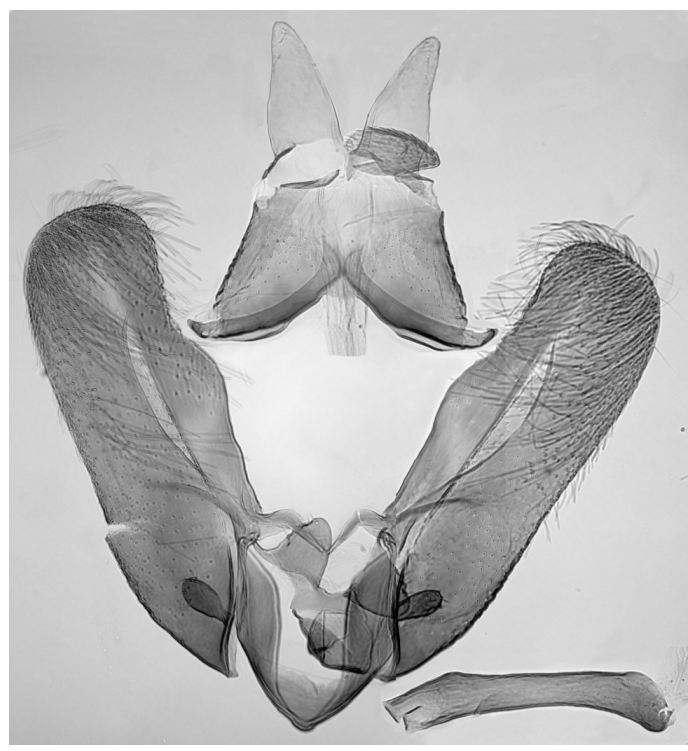

Fig. 13. Elachista arduella sp. n. ơ genitalia (holotype, L. Kaila prep. n. 3381).

Nupponen leg.; Moskovo 22.VI.1996 2 07 K. Nupponen, J.-P. Kaitila, J. Junnilainen \& M. Ahola leg., 10.VII.1997 7 O' K. Nupponen \& J. Junnilainen leg., 1 O J.-P. Kaitila leg; Berlin 30.VI.-1.VII.1997 3 O' K. Nupponen \& J. Junnilainen leg.; Sakmara river 21.VI.1996 1 o K. Nupponen, J.-P. Kaitila, J. Junnilainen \& M. Ahola leg.; Chalk Hills 3.-7.VI.1998 1 O’ J. Junnilainen leg.; Orenburg distr. Orenburgskij Nat. Pk. 12.-17.VI.2001 4 O' J. Kullberg \& M. Zalewski leg.

Distribution. Central and southern Europe, Central Asia, southern Siberia (Kaila 1992).

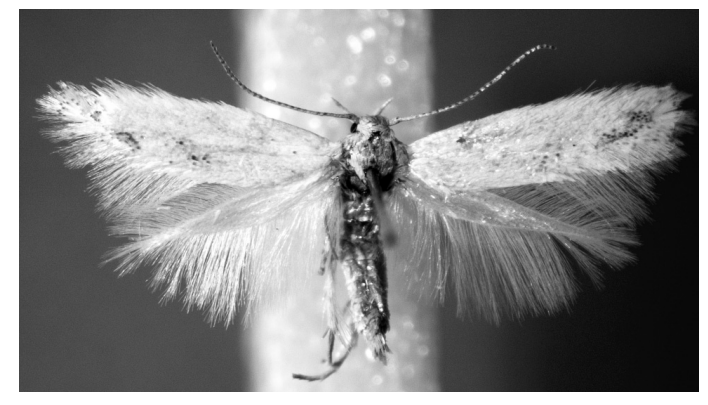

Fig. 12. Elachista arduella sp. n. paratype q.

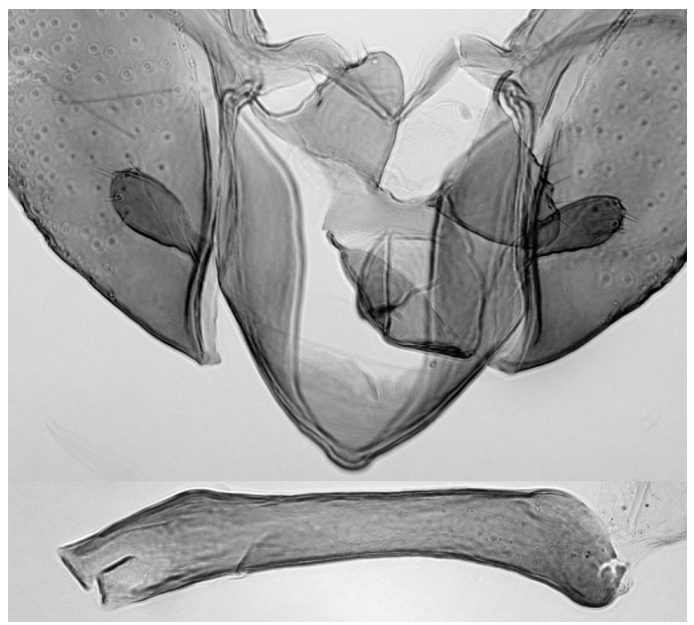

Fig. 14. Elachista arduella sp. n., juxta, digitate process and aedeagus (holotype, L. Kaila prep. n. 3381).

\section{Elachista (Aphelosetia) nolckeni Šulcs, 1992}

Elachista disertella auct., nec Herrich-Schäffer, 1855

Miass 26.VI.1997 2 ○’, 28.VI.1997 1 우, 30.VI.1997 1 O K K. Nupponen \& J. Junnilainen leg.; 26.VI.1997 1 O’ J.-P. Kaitila leg.; 24.VI.2001 1 O’ K. Nupponen leg.; Moskovo 10.VII.1997 1 O’ J.-P. Kaitila leg.

Distribution. Central Europe.

Remarks. New to Russia.

\section{Elachista (Aphelosetia) arduella Kaila sp. n.} (Figs. 11-15)

Holotype $0^{7}$ : Russia, S. Ural, Orenburg distr. $50^{\circ} 40-45^{\prime} \mathrm{N} 54^{\circ} 26-28^{\prime} \mathrm{E}, 170-230 \mathrm{~m}, 20 \mathrm{~km} \mathrm{~S}$. 


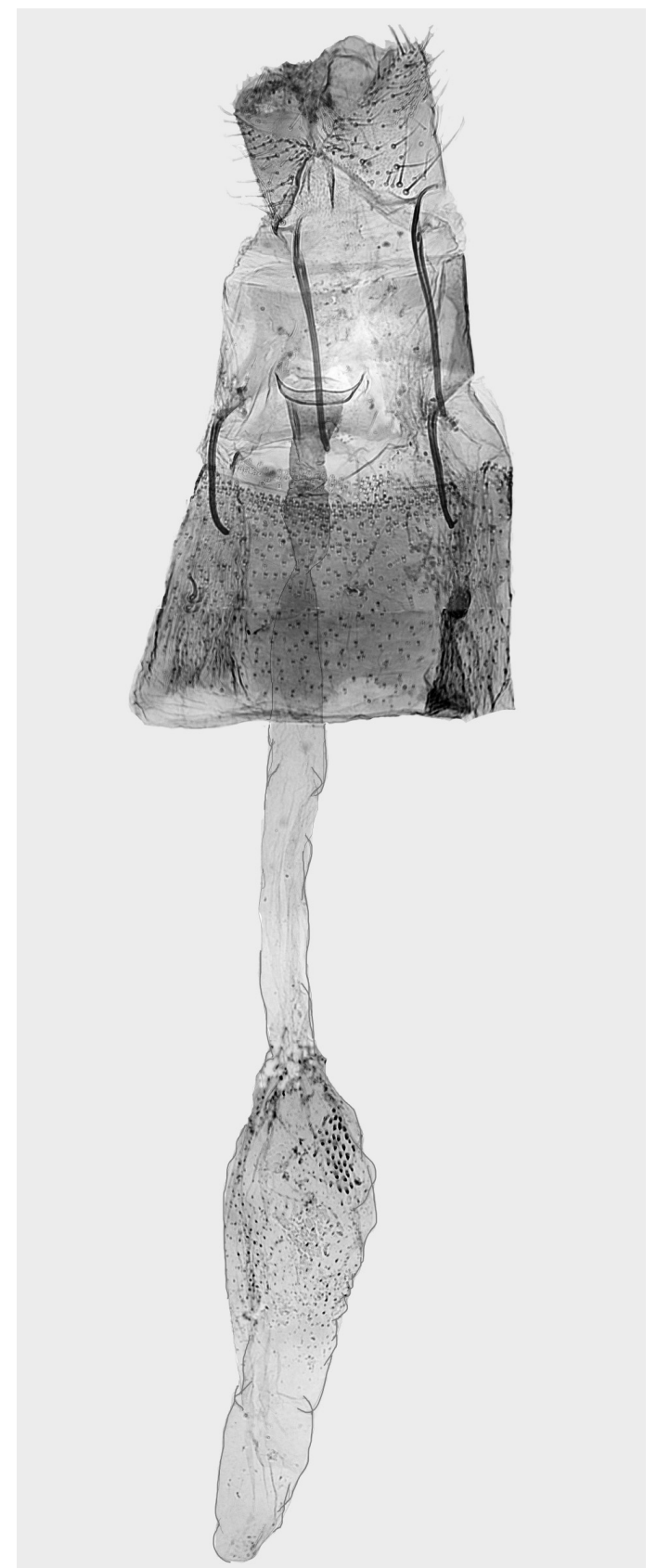

Fig. 15. Elachista arduella sp. n. o genitalia (paratype, L. Kaila prep. n. 3633).

Pokrovka village, Schibendy Valley 11.VI.2001 K. Nupponen leg. L. Kaila prep. n. 3381 (in coll. Nupponen). Paratypes (6 \%): 1 \% with the same collecting data as in the holotype (L. Kaila prep. n. 3629); the same locality, 3 VI.1998 1 o (L.

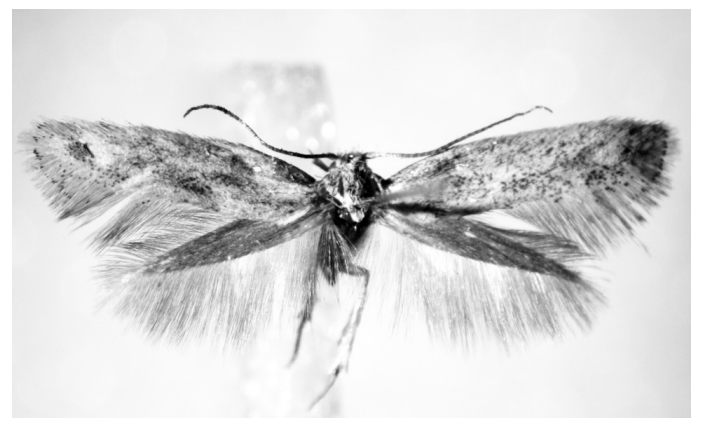

Fig. 16. Elachista gibbera sp. n. holotype ơ.

Kaila prep.n. 3633), 5.VI.1998 2 ㅇ (1 \& dissected, L. Kaila prep. n. 3630), 6.VI.1998 1 \&, 23.VI.1999 (L. Kaila prep. n. 3634) 1 ㅇ T. \& K. Nupponen leg.

Diagnosis. Elachista arduella sp. n. belongs to those species in the sg. Aphelosetia that have a broad and shallow dorsally directed median sac in the median plate of juxta. Its very small-sized juxta and digitate process indicate a close relationship with E. atrisquamosa Staudinger and $E$. ohridella Parenti. Externally E. arduella differs from E. atrisquamosa by its paler and strongly mottled wing pattern and by its thicker antennae. The male genitalia of these species differ by the shape of the juxta lobes which are medially more expanded in E. arduella than in E. atrisquamosa (cf. Schmidt Nielsen \& Traugott-Olsen (1978). The aedeagus of $E$. atrisquamosa is narrower and gradually tapered towards apex while that of $E$. arduella is broadest near apex. E. ohridella is white with faint yellowish maculation in the forewings, and the male genitalia differ by the shape of the aedeagus being distally broader in $E$. arduella than in E. ohridella (cf. Parenti (2002).

Description of ơ. Wing span $7.6 \mathrm{~mm}$. Labial palpus 0.9 times the diameter of head, greyish white, below dusted with leaden grey scales especially at third segment. Sides of head narrowly creamy white, head otherwise leaden grey, mixed with paler scales; neck tuft greyish white. Tegula medially shiny grey, otherwise creamy white; thorax creamy white. Scape of antenna shiny grey, flagellum thick, dark grey, articles annulated with distinctive pale rings. Fore- and midleg outwardly shiny grey, inwardly pale grey, tibia and tarsal articles distally pale grey; hindleg unicolorous greyish white. Forewing ground colour creamy 


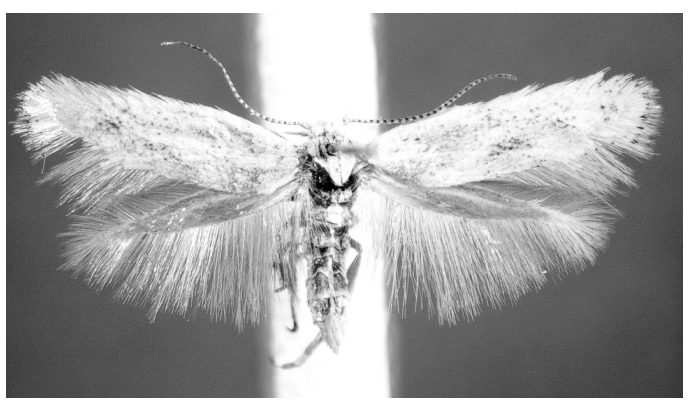

Fig. 17. Elachista gibbera sp. n. paratype $ᄋ$.

white, with the following irregular patches formed of brownish grey tipped scales: broadly along basal third, and from middle to distal 5/6 of costal margin; between fold and dorsal margin one oblique patch at basal third and another just beyond middle of wing length; an oblique dark grey stripe from apex to tornus. Shorter fringe scales distally dark brownish grey forming a fringe line; fringe creamy white except at tornus grey. Underside dark grey; fringe creamy white except at tornus grey. Hindwing translucent, pale bluish grey, fringe pale ochreous grey; underside as above.

Female otherwise as male, but flagellum of antenna thinner; forewing silky white, indistinctly irrorated with ochreous yellow, with an indistinctly delimited brownish grey patch at distal 2/ 3 length of wing margin, and another elongate, often darker patch along outer margin.

Male genitalia: Uncus lobes triangular, 1.5 times longer than wide, tapered to narrowly rounded apex, separated by V-shaped incision. Mesial knob of gnathos basally narrow, ovalshaped and distally pointed. Juxta small; median plate with shallow posteriorly directed median sac; juxta lobes widely separated from each other, medially produced, median margin somewhat convex joining distal margin without an angle; distal margin with a few setae, straight; lateral margin concave. Digitate process short, setose, blunt, basally very narrow. Valva broad; basal and distal fold of costa meet at half of the length of valva, costa medially weakly convex; sacculus straight, meeting cucullus without an angle; distal margin of cucullus straight. Aedeagus half the length of valva, medially narrowest, with short caecum; distally bent with an obtuse angle; distal opening with two folded lobes, extended to $3 / 5$ length of aedeagus; cornuti absent.

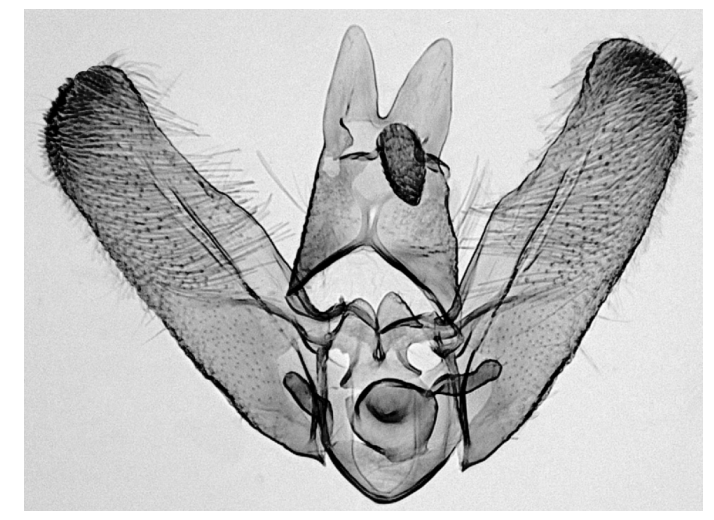

Fig. 18. Elachista gibbera sp. n. ơ genitalia excluding aedeagus (holotype, L. Kaila prep. n. 3626).

Female genitalia: Papillae anales broad triangular, ventrally joined by Y-shaped sclerotisation. Apophyses posteriores stout, twice longer than the nearly straight apophyses anteriores. Ostium bursae situated at sternum 8 ; width of ostium bursae $1 / 3$ of the distance between apophyses anteriores, forming narrow antrum, and abruptly narrowed to very short colliculum; ductus seminalis incepted anterior to colliculum. Ductus bursae about three times longer than apophyses posteriores, membranous and without internal sclerotisations or granules; inserted to oval-shaped corpus bursae without distinct limit. Corpus bursae medially broadly but sparsely covered by blunt spines. Signum formed as rounded group of coarse spines in anterior half of corpus bursae.

\section{Elachista (Aphelosetia) gibbera Kaila sp. n.} (Figs. 16-20)

Holotype $0^{7}$ : Russia, S. Ural, Cheliabinsk dr., $52^{\circ} 39^{\prime} \mathrm{N} 59^{\circ} 00^{\prime} \mathrm{E}, 300 \mathrm{~m} 5 \mathrm{~km}$ S. Kizilskoye near Ural River, 27.V.1998 T. \& K. Nupponen leg. L. Kaila prep. n. 3626 (in coll. Nupponen).

Paratypes (5 $0^{7} 1$ ( $)$ ): $10^{7}$ from the same locality and date as the holotype, J. Junnilainen leg., 2 $0^{7} 1$ 우 T. \& K. Nupponen leg.; Cheliabinsk oblast, $53^{\circ} 57^{\prime} \mathrm{N} 59^{\circ} 03^{\prime} \mathrm{E}, 650 \mathrm{~m}$, near Moskovo village 26.V.1998 2 O’ J. Junnilainen leg., 1 O' T. \& K. Nupponen leg.

Diagnosis. Elachista gibbera sp. n. also belongs to those species in the sg. Aphelosetia that have a broad and shallow dorsally directed me- 


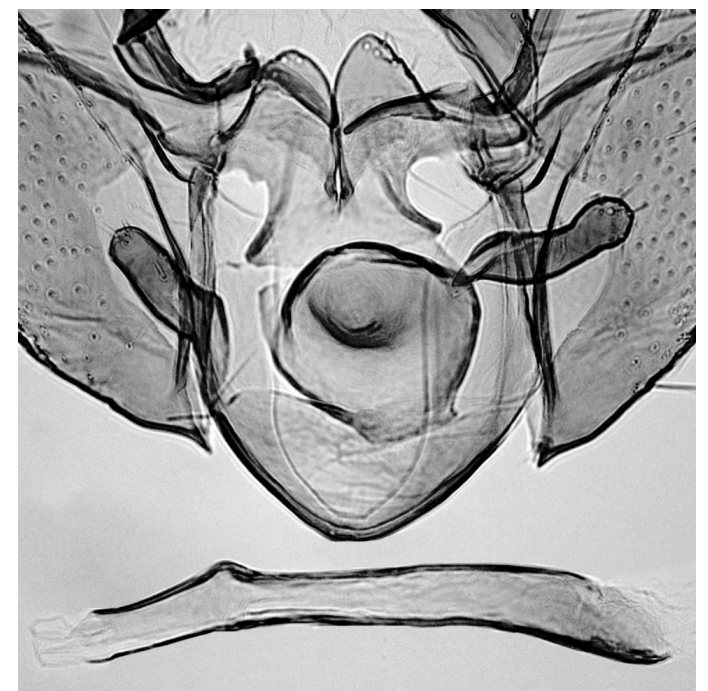

Fig. 19. Elachista gibbera sp. n., juxta, digitate process and aedeagus (holotype, L. Kaila prep. n. 3626).

dian sac in the median plate of juxta. It closest resembles the male genitalia of E. maculosa Parenti, described from Afghanistan. The shape of the uncus lobes however differs significantly being longer and distally tapered in E. gibbera, while they are widely rounded in E. maculosa. The mesial knob of the gnathos is also more acutetipped in E. gibbera than in E. maculosa (cf. Parenti (1981)).

Description. Wing span 9.9-11.7 mm. Labial palpus as long as diameter of head, creamy white, slightly dusted with pale grey scales below. Head and neck tuft creamy white. Tegula and thorax creamy white, variably suffused with brownish grey scales. Scape of antenna creamy white, variably dusted with grey, flagellum dark grey, articles annulated with pale rings. Foreleg outwardly dark grey, inwardly pale, midleg pale grey, tibius suffused with grey, tarsal articles dark grey with pale distal rings, hindleg pale ochreous. Forewing ground colour creamy white, densely suffused with dark grey tipped scales that are patchily aggregated, leaving the following creamy white pattern: at basal $1 / 3$ indistinct medially outwards angled fascia, smaller irregular patches at distal half of the wing, especially at tornus and near apex; shorter fringe scales distally dark grey forming fringe line; fringe grey except along termen creamy white. Underside dark grey; fringe grey

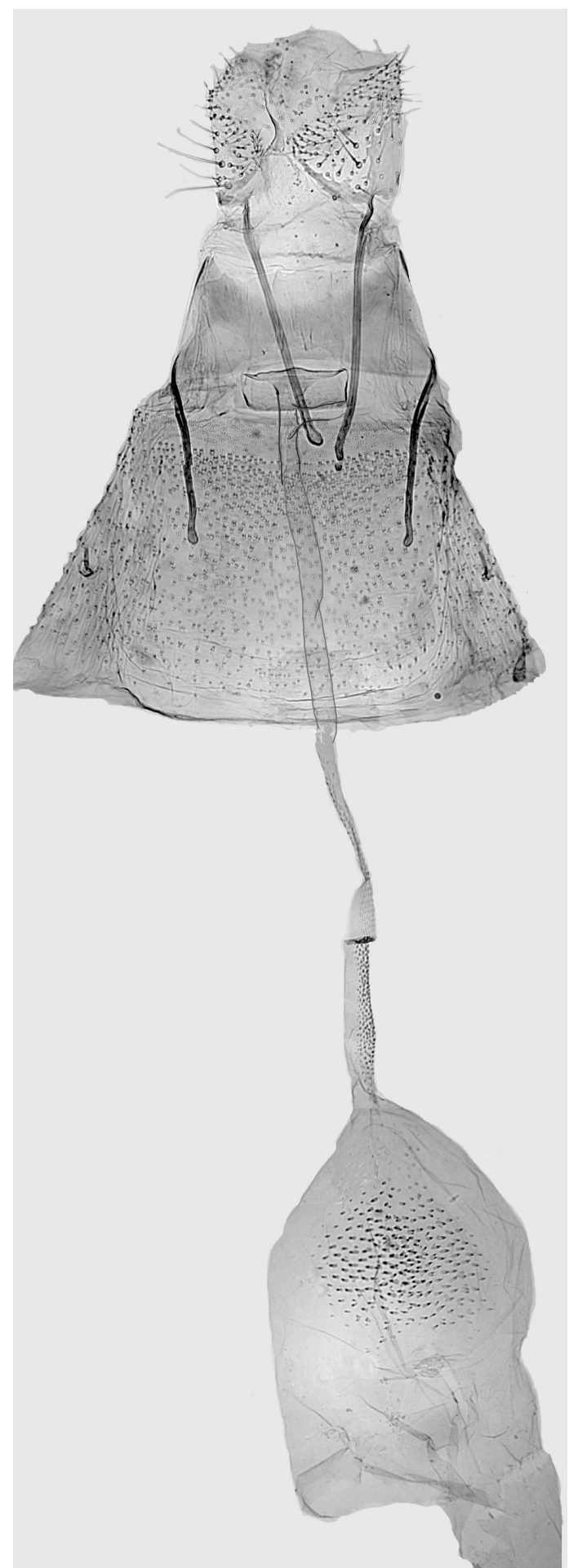

Fig. 20. Elachista gibbera sp. n. $\bigcirc$ genitalia (paratype, L. Kaila prep. n. 3628). 
except along termen white. Hindwing grey, fringe ochreous grey; underside as above.

Male genitalia: Uncus lobes triangular, almost twice longer than wide, tapered to narrowly rounded apex, separated by V-shaped incision. Mesial knob of gnathos basally broad, oval-shaped and distally pointed. Median plate of juxta with shallow posteriorly directed median sac; juxta lobes medially produced, median margin somewhat convex joining distal margin without an angle; distal margin with a few setae, straight; lateral margin concave. Digitate process short, setose, blunt, basally very narrow. Valva broad; basal and distal fold of costa meet at half of the length of valva, costa medially weakly convex; sacculus straight, meeting cucullus without an angle; distal margin of cucullus straight. Aedeagus half the length of valva, narrow, with short caecum; distally bent with an obtuse angle and forming swelling dorsally; distal opening simple; cornuti absent in vesica.

Female genitalia: Papillae anales broad triangular, ventrally joined by Y-shaped sclerotisation. Apophyses posteriores straight, 1.5 times longer than the nearly straight apophyses anteriores. Ostium bursae situated at posterior margin of sternum 8 which is transformed as quadrangular plate anterior to ostium bursae; width of ostium bursae $1 / 3$ of distance between apophyses anteriores, abruptly narrowed to very short colliculum, without sclerotised reinforcements; antrum absent, ductus seminalis incepted anterior to colliculum. Ductus bursae about three times longer than apophyses posteriores, membranous and without internal sclerotisations, at anterior half laterally covered with minute granules; abruptly inserted to oval-shaped corpus bursae. Signum formed as large group of coarse spines in anterior half of corpus bursae; otherwise no internal spines present.

\section{Elachista (Aphelosetia) constitella Frey, 1859}

Kidriasovo 28.V.1998 1 O’, 16.VI.1999 1 Ơ T. \& K. Nupponen leg.; Orenburg distr. Orenburgskij Nat. Pk. 12.-17.VI.2001 1 O' J. Kullberg \& M. Zalewski leg.; Verbljushka 30.V.-5.VI.1998 1 O’ J. Junnilainen leg.; $20 \mathrm{~km}$ S. Pokrovka village, Schibendy valley 3.-7.VI.1998 1 O’ J. Junnilainen leg.
Remarks. E. constitella was omitted from the checklist of European Elachistidae (Parenti 1996). The genitalia of its female lectotype were illustrated by Parenti (1977), and the male genitalia by Traugott-Olsen (1990b). E. constitella is at least known from Croatia, Italy and Turkey. $E$. maculata Parenti, described from Turkey: Konya (Parenti 1978) may also be referable to $E$. constitella Frey, but we are not willing to establish an uncertain new synonymy in this context. If these species prove to be synonyms, the records of E. maculata Parenti from Bulgaria and Creece (Parenti 1996) would also be attributable to $E$. constitella Frey. New to Russia.

\section{Elachista (Aphelosetia) nitidulella (Herrich- Schäffer, 1855)}

Arkaim 14.VI.1996 1 O’ K. Nupponen, J.-P. Kaitila, J. Junnilainen \& M. Ahola leg.

Distribution. Central Europe (Parenti 1996). Remarks. New to Russia.

\section{Elachista (Aphelosetia) manni Traugott-Olsen, 1990}

Kizilskoye 27.V.1998 4 07 J. Junnilainen leg., 11 O'T. \& K. Nupponen leg.; Moskovo 26.V.1998 3 O’ J. Junnilainen leg., 4 O' T. \& K. Nupponen leg.; Kidriasovo 28.-29.V.1998 2 O’ 1 ㅇ J. Junnilainen leg., 1 주 1 우 T. \& K. Nupponen leg.

Distribution. Central and Eastern Europe (Parenti 1996). Traugott-Olsen (1990a) mentions it also from Russia: Volgograd.

Remarks. The identification is based on Traugott-Olsen (1990a). However, examination of the lectotype of Elachista festucicolella Zeller, 1853 suggests that these taxa may be synonyms. We are not, however, willing to establish an uncertain synonymy between these taxa in the present context, and therefore follow the current use of these names.

\section{Elachista (Aphelosetia) flavescens Parenti, 1981} (Figs. 21 and 22)

Chalk Hills 3.-7.VI.1998 2 O' J. Junnilainen leg., 1 O' T. \& K. Nupponen leg., 22.VI.1999 1 O’ T. \& 


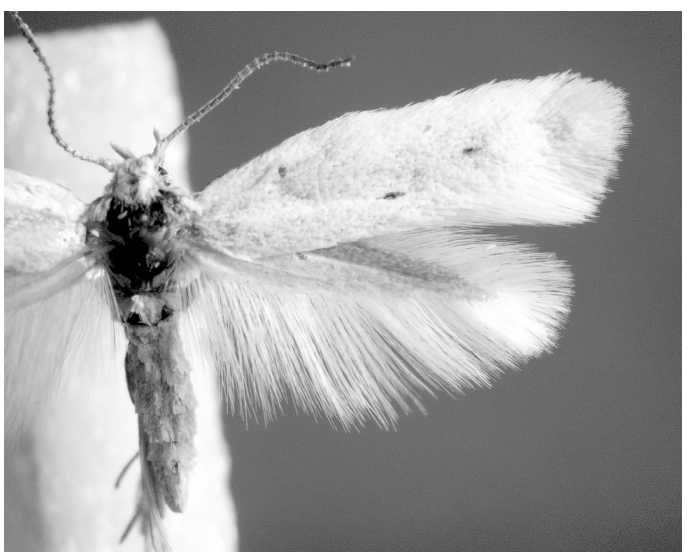

Fig. 21. Elachista flavescens Parenti ơ (Russia: Volgograd).

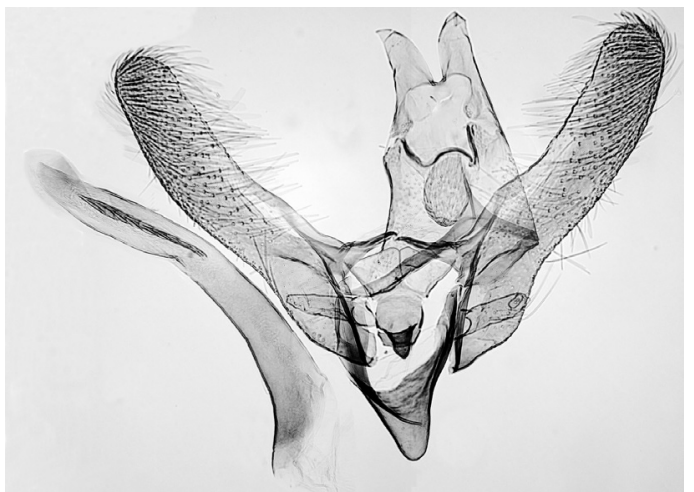

Fig. 22. Elachista flavescens Parenti, on genitalia (Russia: Volgograd, L. Kaila prep. n. 3407).

K. Nupponen leg.; Volgograd distr., 80 km NW Volgograd nr. Ilovla village 2.VI.2001 $20^{7} \mathrm{~K}$. Nupponen leg.

Distribution. Turkey, Armenia (Parenti 1981). Remarks. New to Russia.

Elachista (Aphelosetia) acutella Kaila sp. n. (Figs. 23 and 24)

Holotype 0': Russia, S. Ural, Orenburg distr., $51^{\circ} 23$ N 56 $49^{`}$ E, 130-340 m, 6 km W Donskoje village, Mt. Verbljushka, 10.VI.1998 T. \& K. Nupponen leg. L. Kaila prep. n. 3390 (in coll. Nupponen).

Paratypes $\left(3 \sigma^{7}\right)$ : the same locality, 10.12.VI.1998 1 O’ J. Junnilainen leg., 2 O' T. \& K. Nupponen leg.

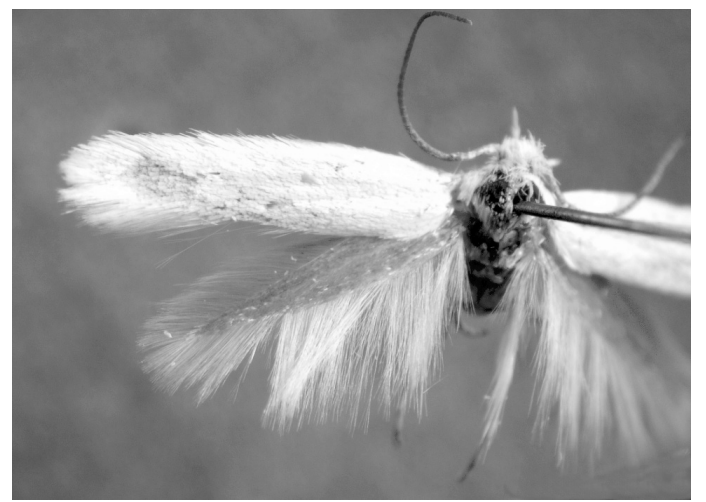

Fig. 23. Elachista acutella sp. n. holotype o".

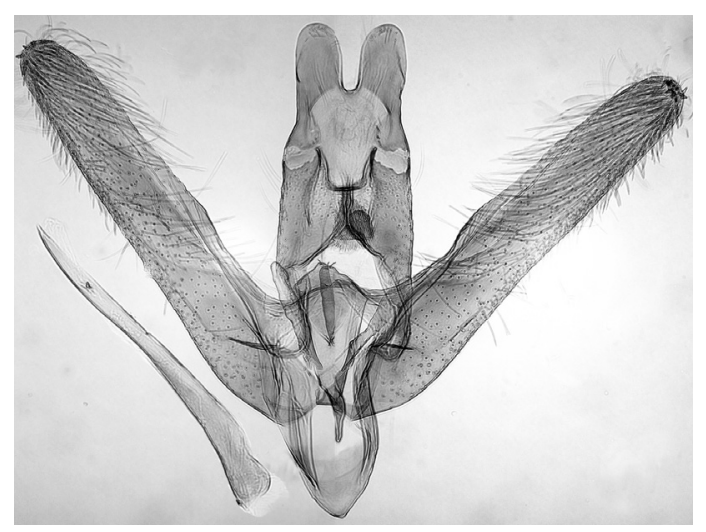

Fig. 24. Elachista acutella sp. n. o' genitalia (holotype, L. Kaila prep. n. 3390).

Diagnosis. Elachista acutella sp. n. closely resembles E. bimaculata Parenti, E. mus Parenti and E. semnani Parenti. From these species it is readily separated by its much longer uncus lobes (cf. Parenti (1981)).

Description. Wing span 9.5-10.3 mm. Labial palpus as long as diameter of head, nearly straight, bluish white. Head, neck tuft, tegula, thorax, scape and pedicel of antenna bluish white. Foreleg inwardly dark brownish grey, outwardly pale grey, tibius and tarsal articles with bluish white distal rings; midleg pale grey; hindleg pale grey, spurs and tarsi ochreous. Forewing bluish white, basal $1 / 5$ of costa dark grey; small brown spot in the middle of wing at fold, and another similar spot at distal 1/4 of wing; fringe concolorous with ground colour. Underside dark grey, dorsal area pale grey, fringe pale ochreous. Hindwing bluish 


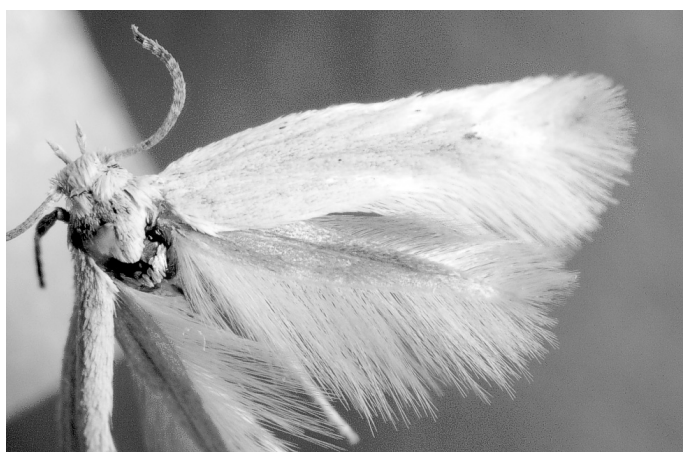

Fig. 25. Elachista chamaea sp. n. holotype ơ (Russia: Tuva Rep. Kyzyl).

grey, fringe scales basally ochrous grey, distally bluish white; costal area of underside dark grey, dorsal area bluish white, fringe scales basally ochreous grey, distally bluish white.

Male genitalia: Uncus lobes somewhat longer than wide, distally broadly rounded and with a few setae ventrodistally. Mesial knob of gnathos basally narrow, oval-shaped. Median plate of juxta with deep tongue-shaped dorsally directed median sac; juxta lobes medially produced, median margin straigth joining distal margin with a sharp angle, distal margin nearly straight joining the straight lateral margin in an obtuse angle. Digitate process narrow, parallel-sided and blunttipped, about $1 / 4$ length of valva. Valva narrow and parallel-sided, about six times longer than wide, basal and distal fold of costa joining at $2 / 5$ length of valva. Cucullus basally slightly truncate, otherwise straight joining cucullus without limit. Vinculum U-shaped, without pointed saccus. Aedeagus narrow, 3/4 length of valva, medially slightly bent, broadest basally, tapered to a pointed apex; vesica with small blunt tooth-shaped cornutus inserted in small sclerotised plate.

\section{Elachista (Aphelosetia) spumella Caradja, 1920}

Arkaim 22.-23.VII.1998 3 O' K. Nupponen leg.; Chalk Hills 6.VI.1998 1 O' T. \& K. Nupponen leg., 3.-7.VII.1998 2 రా J. Junnilainen leg.; Kandrykul 30.V.2001 $10^{7} 1$ 우 K. Nupponen leg.; Kidriasovo 28.-29.V.1998 13 O J. Junnilainen leg., 2 O' T. \& K. Nupponen leg.; Kizilskoye 27.V.1998 3 ơ J. Junnilainen leg., 8 ơ 1 ㅇ T. \& K. Nupponen leg., 26.VII.2000 $2 \sigma^{7}$ T. Nupponen

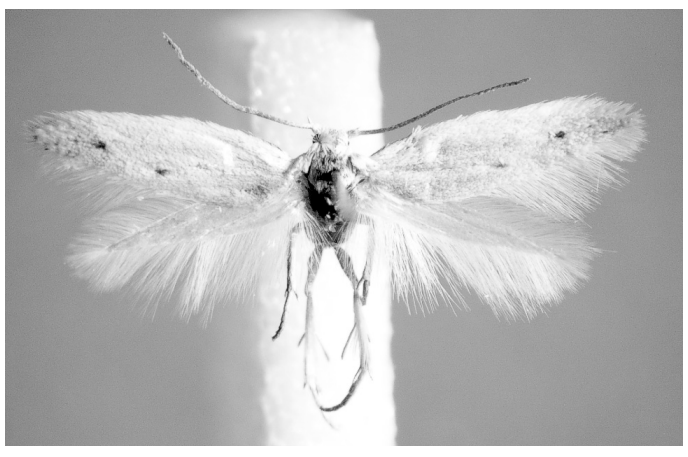

Fig. 26. Elachista chamaea sp. n. ơ (Russia: Orenburg dr.).

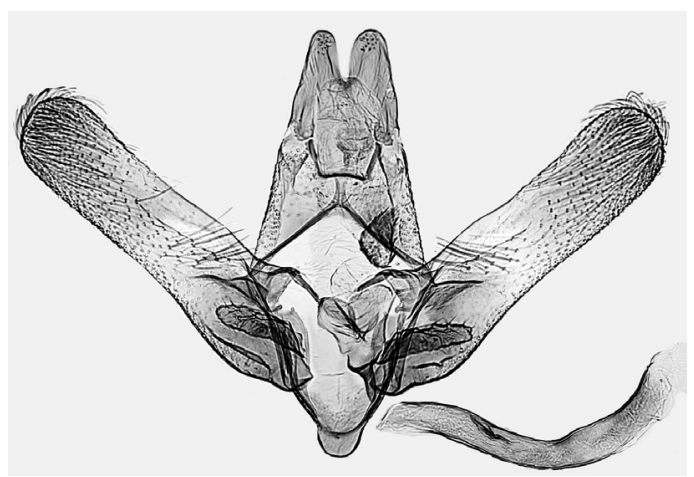

Fig. 27. Elachista chamaea sp. n. ơ genitalia (holotype, L. Kaila prep.n. 1659).

leg.; Moskovo 26.V.1998 3 O’ J. Junnilainen leg., 11.-12.VII.1998 3 ơ 1 우 K. Nupponen leg.; Kuvandyk 19.VII.1998 2 O' K. Nupponen leg.; Verbljushka 30.V.-12.VI.1998 2 O' J. Junnilainen leg. 30.V.1998 1 O’, 14.-16.VII.1998 5 O’ T. \& K. Nupponen leg., 13.V.1999 1 O’ K. Nupponen leg.

Distribution. Transpalaearctic in steppe regions.

Elachista (Aphelosetia) chamaea Kaila sp. n. (Figs. 25-29)

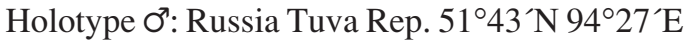
Kyzyl, 700m, nanophyton-steppe 5.-6.VI.1994 Jalava \& Kullberg leg., L. Kaila prep. n. 1659 (in coll. ZMH); Paratypes (2 $\left.0^{7}\right)$ : $10^{7}$ with the same collection data as in the holotype, L. Kaila prep. n. 1662; Tuva Rep., Kyzyl 21.V.1990 1 O’ V. Dubatolov leg., L. Kaila prep. n. 2208 (Coll. Zoological Museum, Novosibirsk). 


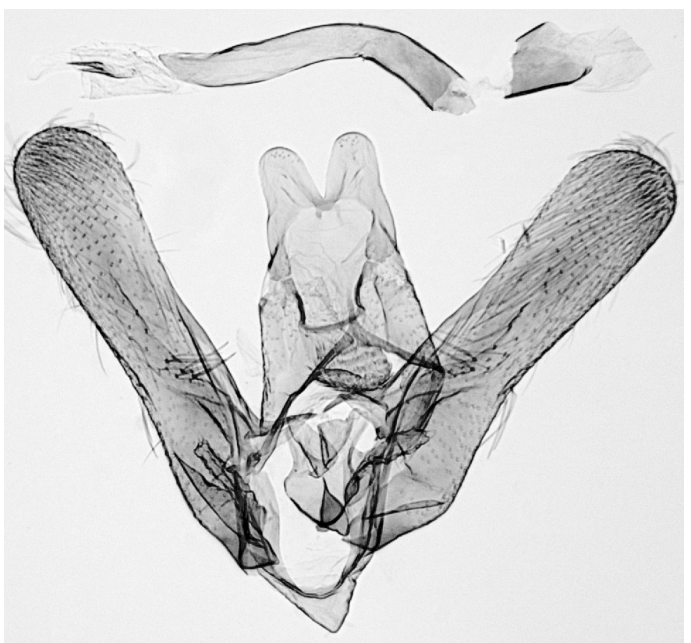

Fig. 28. Elachista chamaea sp. n. ơ genitalia (Russia: Orenburg dr., L. Kaila prep. n. 3402).

Other material: Russia, S. Ural, Orenburg dr., $50^{\circ} 40-45^{\prime} \mathrm{N} 54^{\circ} 26-28^{\prime} \mathrm{E}, 170-230 \mathrm{~m}, 20 \mathrm{~km} \mathrm{~S}$ Pokrovka village, Schibendy Valley 11.VI.2001 $10^{7}$ K. Nupponen leg. L. Kaila prep. n. 3402.

Diagnosis. Elachista chamaea sp. n. is a close relative of $E$. cornuta Parenti, described from Iran. These species differ in the shape of aedeagus being longer in E. chamaea than in E. cornuta. The cornutus is elongate and with one or two straight teeth in E. chamaea, but with one short and stout, bent tooth in E. cornuta (cf. Parenti 1981)).

Description. Wing span 9.3-10.8 mm. Labial palpus as long as diameter of head, bluish or greyish white, variably suffused with grey below. Head, neck tuft, tegula, thorax, scape and pedicel of antenna brownish white, basal 1/4 of flagellum whitish, flagellum otherwise pale brownish grey. Fore- and midleg grey, hindleg pale grey. Forewing brownish white, basal 1/4 of costa dark grey; elongate brownish grey spot sometimes in the middle of wing at fold, and another similar spot at distal 1/4 of wing; fringe concolorous with ground colour. Underside dark grey, fringe scales ochreous. Hindwing translucent, bluish grey, fringe ochreous white; underside grey, costa somewhat darker; fringe scales ochreous.

Male genitalia: Uncus lobes slightly broader than long, distally broadly rounded and with group of setae ventrodistally. Mesial knob of gnathos broader than long, rounded. Median plate of juxta with broad tongue-shaped dorsally directed me-

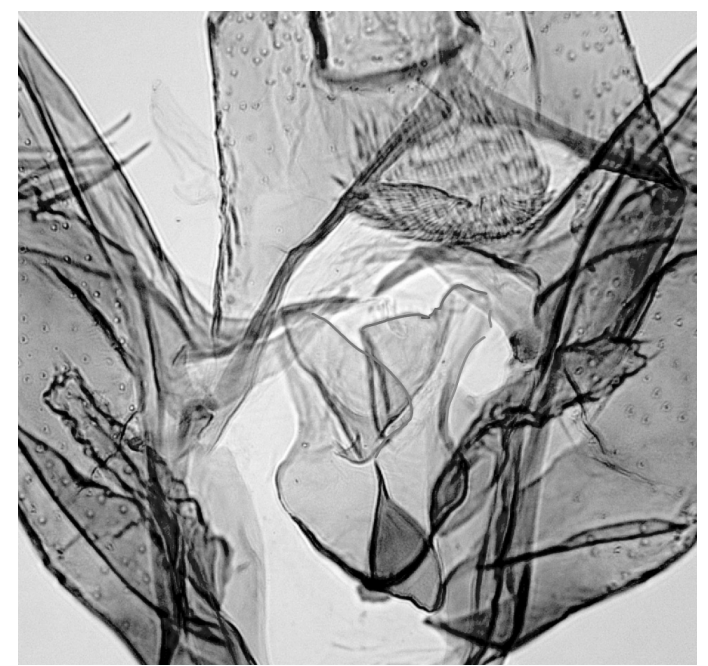

Fig. 29. Elachista chamaea sp. n., gnathos, juxta and digitate process (Russia: Orenburg distr., L. Kaila prep. n. 3402).

dian sac; juxta lobes laterally produced, median margin somewhat convex, joining distal margin almost without an angle; distal margin mesially almost straight, laterally somewhat truncate; lateral margin concave. Digitate process parallelsided, blunt-tipped, 1/5 length of valva. Valva parallel-sided, about 4.5 times longer than wide, basal and distal fold of costa joining at 1/3 length of valva. Cucullus basally slightly truncate, otherwise straight joining cucullus without limit. Vinculum U-shaped, with very short and broad saccus. Aedeagus bent, parallel-sided, 6/7 length of valva, tapered to blunt apex; vesica with one straight elongate cornutus formed as one or two straight elongate teeth arising from elongate sclerotised plate, length of cornutus about $1 / 7$ length of aedeagus.

\section{Elachista(Aphelosetia) galacticella (Eversmann, 1844)}

Verbljushka, 10.VI.1998 1 O' T. \& K. Nupponen leg., 14.VII.19982 O', 15.VII.1998 1 O’ K. Nupponen leg., 19.VI.1999 2 O’ T. \& K. Nupponen leg.

Distribution. Spain, Switzerland, S. Urals (Parenti 2001).

Remarks. E. galacticella was originally described from Orenburg district. Kaila (1999a) considered E. deresyensis Traugott-Olsen, from Turkey, to be a synonym of E. galacticella. Re- 


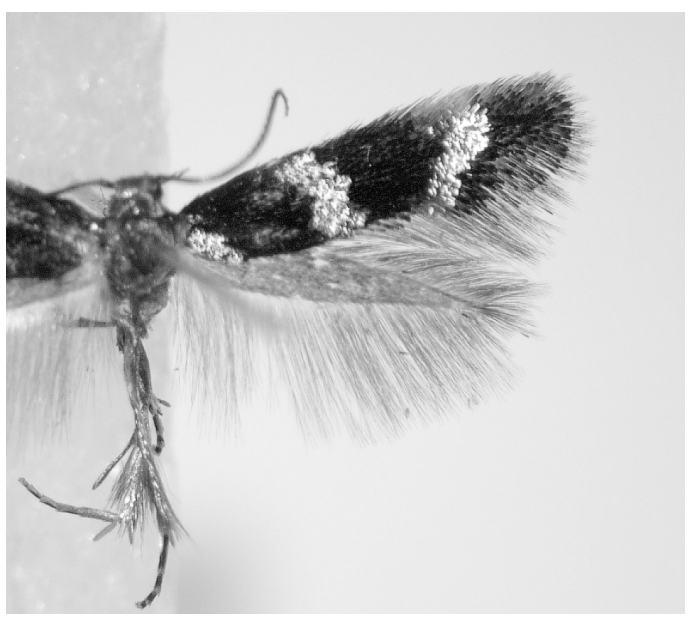

Fig. 30. Elachista megagnathos Sruoga ơ (Verbljushka).

cently collected series of specimens from Turkey apparently representing this taxon, however, indicate that $E$. deresyensis could be distinct from E. galacticella. Further study is needed.

\section{Elachista (Aphelosetia) sp. nr. dispunctella (Duponchel, 1843)}

Russia Volgograd distr. 80 km NW Volgograd nr. Ilovla village 2.VI.2001 7 O' K. Nupponen leg.

Remarks. Traugott-Olsen (1992) gave a taxonomic treatment for $E$. dispunctella Duponchel and its relatives. The complex was classified to consist of no less than 53 Western Palaearctic species, 44 of which he described as new. At least some of these descriptions were based on minute differences in their wing venation pattern, which later were dismissed by Albrecht and Kaila (1997). We agree with Traugott-Olsen (1992) in that many species probably are involved in this complex. However, their delimitation is in need of a thorough re-evaluation. Therefore we resign from attempting to find a name for the present specimens.

\section{Elachista (Elachista) gleichenella (Fabricius, 1781)}

Miass 26.-27.VI.1997 5 ơ 16 우 K. Nupponen \& J. Junnilainen leg., 26.VI.1997 2 O’ J.-P. Kaitila leg. Distribution. Europe, Siberia (Kaila 1992), Russian Far East (Sinev \& Sruoga 1997).

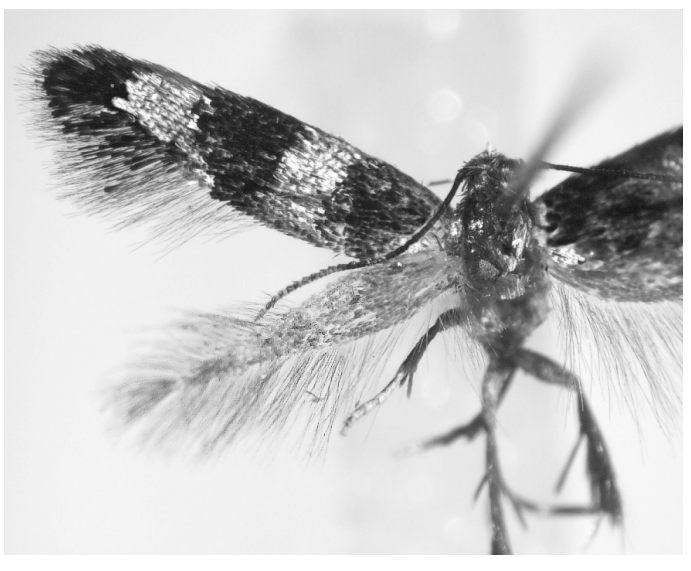

Fig. 31. Elachista megagnathos Sruoga 9 (Verbljushka).

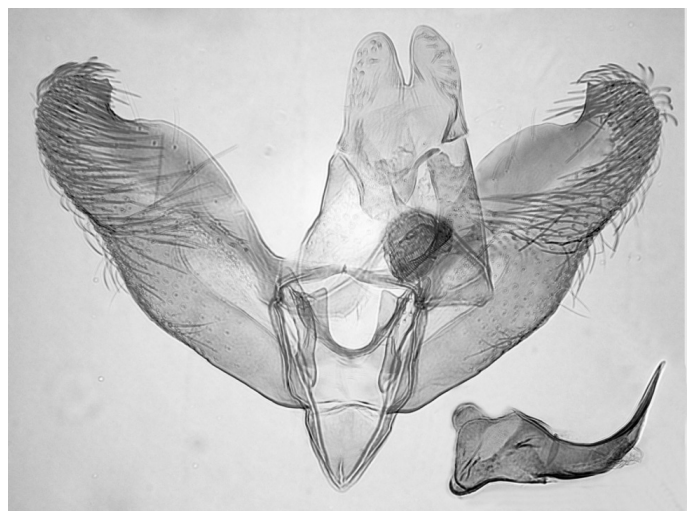

Fig. 32. Elachista megagnathos Sruoga ơ genitalia (Verbljushka, L. Kaila prep. n. 3155).

Remarks. Parenti (1983) reported E. gleichenella from Japan. The Japanese population represents, however, a distinct species (K. Sugisima, in preparation).

\section{Elachista (Elachista) megagnathos Sruoga, 1990 (Figs. 30-34)}

Verbljushka 11.VI.1998 1 \&, 12.VI.1998 1 O’ T. \& K. Nupponen leg.

The original description of E. megagnathos was based on two male specimens from Russian Far East. The male of the present material agrees with the description of E. megagnathos, and V. Sruoga (pers. comm.) has confirmed the identification. Since the female has been unknown its description is given here. 


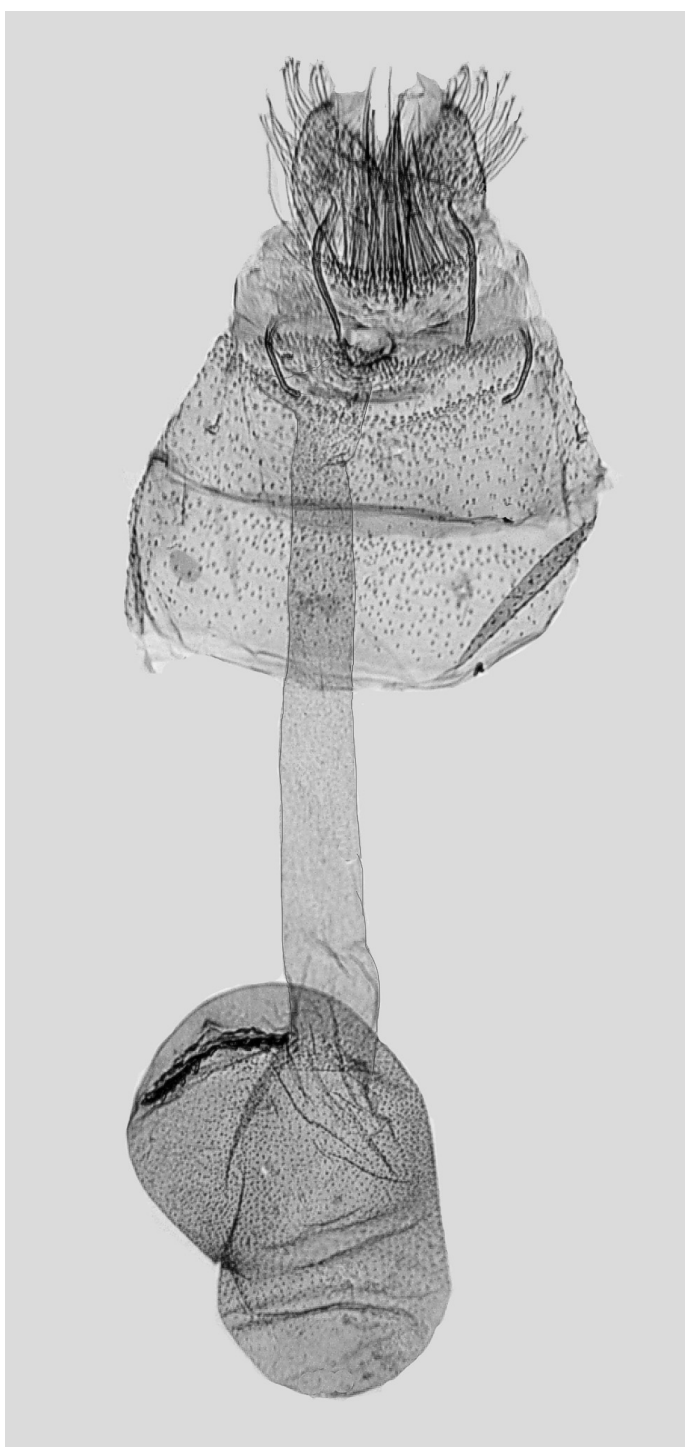

Fig. 33. Elachista megagnathos Sruoga $\odot$ genitalia (Verbljushka, L. Kaila prep. n. 3318).

Description of O. Wing span $6.8 \mathrm{~mm}$. Length of labial palpus equal to diameter of head, drooping, shiny leaden grey above, darker grey below. Head, neck tuft, thorax and scape of antenna shiny leaden grey. Flagellum dark grey, weakly annulated with somewhat paler grey rings. Legs shiny leaden grey, tibia and tarsal segments ochreous below, and annulated with pale rings. Forewing ground colour shiny blackish grey, base paler with metallic iridescence, a broad fascia before middle of wing length, and another broad fascia at distal 4/

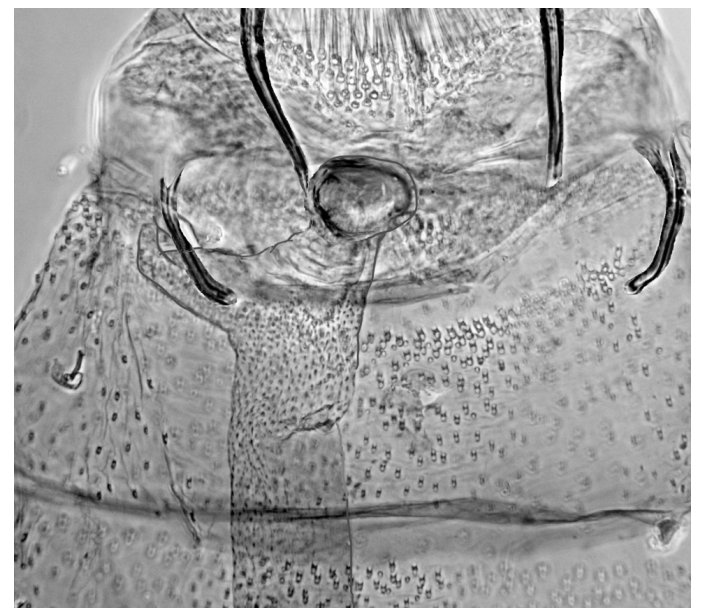

Fig. 34. Elachista megagnathos Sruoga o ostium bursae, colliculum and ductus seminalis (Verbljushka, L. Kaila prep. n. 3318).

5 of wing length of same colour. Hindwing acutetipped, grey. Underside of wings leaden grey.

Female genitalia: Papillae anales triangular, with long distally hook-shaped setae. Apophyses posteriores stout, basally bent, apophyses anteriores stout, bent, half the length of apophyses posteriores. Membrane between papillae anales and T8 with a dense group of long setae. Ostium bursae rounded, narrowly sclerotised, situated in S8; antrum absent; colliculum shorter than apophyses anteriores, somewhat sclerotised. Ductus bursae broad, membranous, posteriorly covered with minute internal spines; without other sclerotisations, four times longer than apophyses posteriores, abruptly incepted to corpus bursae. Corpus bursae reniform, covered by internal spines except distally; signum large, dentate, boomerang-shaped.

Distribution. Previously only recorded from Russian Far East (Sruoga 1990).

Remarks. New to Europe. The specimens were found at active flight during afternoon.

Elachista (Elachista) sp. nr. biatomella (Stainton, 1848) (Figs. 35 and 36)

Ajat River 4.VII.1997 1 ర’ K. Nupponen \& J. Junnilainen leg.; Arkaim 9.VII.1997 1 రౌ K. Nupponen \& J. Junnilainen leg., 15.VI.1999 2 0" T. \& K. Nupponen leg.; Kidriasovo 28.-29.V.1998 


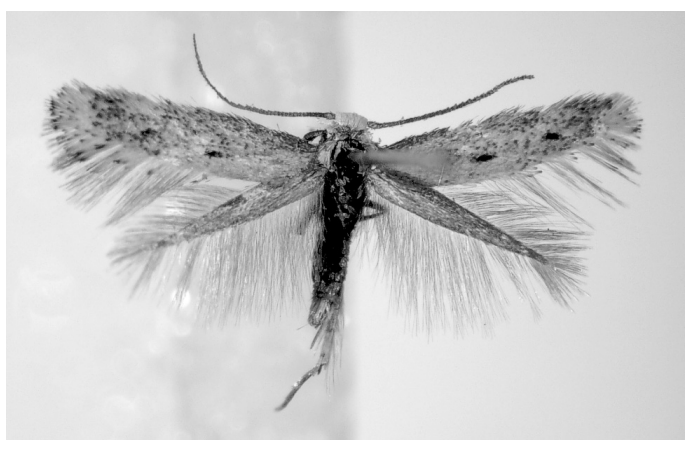

Fig. 35. Elachista nr. biatomella (Stainton) $0^{7}$ (Cheliabinsk distr., Moskovo).

1 O’ J. Junnilainen leg.; Kizilskoye 28.V.1998 1 Ơ T. \& K. Nupponen leg.; Kuvandyk 19.VII.1998 2 O' K. Nupponen leg.; Moskovo 26.V.1998 1 0" J. Junnilainen leg., 3 ơ T. \& K. Nupponen leg.; Sakmara River 21.VI.1996 $10^{7}$ K. Nupponen, J.P. Kaitila, J. Junnilainen \& M. Ahola leg.; Verbljushka 29.VII.2000 1 우 T. Nupponen leg.

Remarks. The taxonomy of E. biatomella (Stainton) and its close relatives is unsettled. Traugott-Olsen (2000) recognises 11 species in this complex. With few exceptions, identification of these species is hardly possible using the literature available, including this reference. Even examination of the original type material of some of the nominal species (by LK) has not shed much light to the taxonomy. There is a lot variation in the external apperance of specimens originating from different geographic areas. However, it is less obvious when this variation can reliably be linked to characters in, e.g. the male genitalia which seem rather uniform. Since female specimens belonging to this species complex are rare in collections, the range of variation in their morphology within and between populations is insufficiently scrutinised. The nominal taxa with subtle if any morphological differences between each other are E. biatomella (Stainton, 1848), E. christenseni Traugott-Olsen, 2000, E. falirakiensis Traugott-Olsen, 2000, E. nevadella TraugottOlsen, 2000, E. boursini Amsel, 1951, E. glaserella Traugott-Olsen, 2000 and E. kleini Amsel, 1935. Two further species, E. jordanella Amsel, 1935 and E. zabella Chrétien, 1908 are only known from female specimens.

Externally, the specimens from southern Urals are smaller and darker than "typical" E. biatomella

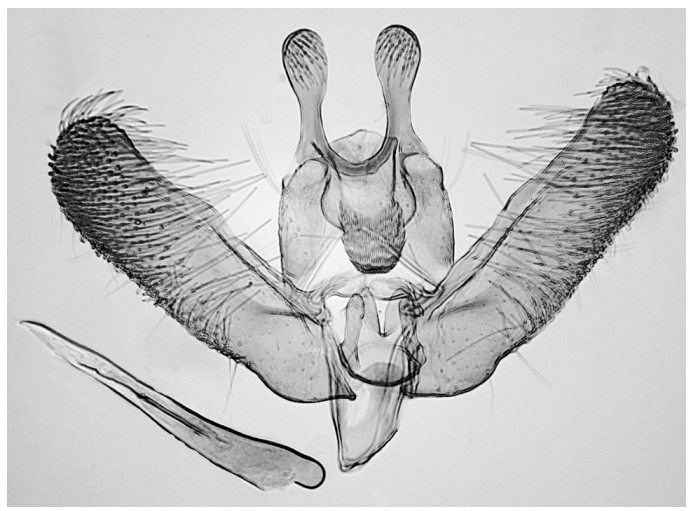

Fig. 36. Elachista nr. biatomella (Stainton) ơ genitalia (Cheliabinsk distr., Moskovo, L. Kaila prep. n. 3131).

specimens from western Europe (Fig. 35). The dark forewing colour seems different from any named species in this complex as shown by Traugott-Olsen (2000). In the absence of any obvious constant differences in the male genitalia of these specimens (Fig. 36) compared to the species listed above we are not willing to intruduce any further names in this complex. At present, identification of the Uralese specimens is not possible to the species level.

\section{Elachista (Elachista) tetragonella (Herrich- Schäffer, 1855)}

Miass 28.VI.1997 1 우 K. Nupponen \& J. Junnilainen leg.

Distribution. Europe.

Remarks. New to Russia.

\section{Elachista (Elachista) martinii Hofmann, 1898}

Miass 26.-27.VI.1996 19 ơ 6 아 K. Nupponen \& J. Junnilainen leg., 13.VI.1996 11 ơ 2 \& K. Nupponen, J.-P. Kaitila, J. Junnilainen \& M. Ahola leg., 19.-20.VI.1998 2 O'T T. \& K. Nupponen leg., 29.V.2001 3 O’, 19.VI.2001 1 Ơ K. Nupponen leg. (4 ơ 1 o in ZMH).

Distribution. Europe, S. Siberia (unpublished specimen from Russia: Altai, Katun valley nr. Katanda 22.VII.1983 Exp. Mikkola, Hippa \& Jalava leg. (ZMH)).

Remarks. New to Russia. 


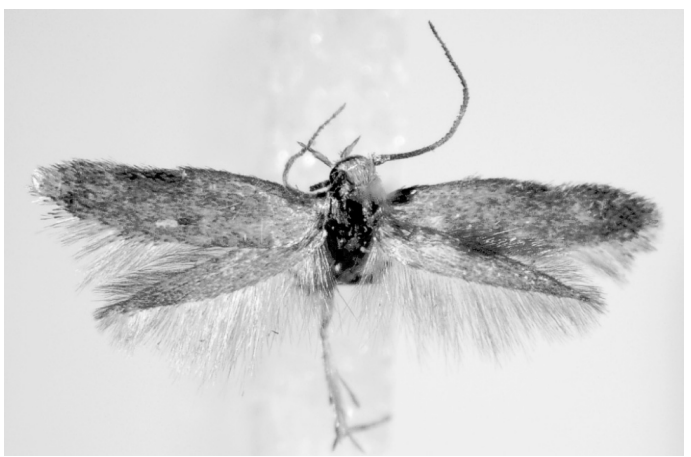

Fig. 37. Elachista devexella sp. n. holotype o"'.

\section{Elachista (Elachista) albidella Nylander, 1848}

Miass 28.VI.1996 1 O’’ K. Nupponen, J.-P. Kaitila, J. Junnilainen \& M. Ahola leg.; Berlin 30.VI.1997 3 O' K. Nupponen \& J. Junnilainen leg.

Distribution. Holarctic (Kaila 1996), (Sugisima 1999).

\section{Elachista (Elachista) contaminatella Zeller, 1847}

Biselachista spinigera Sruoga, 1990

Berlin 1.VII.1997 2 O' 1 ㅇ K. Nupponen \& J. Junnilainen leg.; Arkaim 17.-19.VI.1996 2 O K. Nupponen, J.-P. Kaitila, J. Junnilainen \& M. Ahola leg.; Novoiletzk 9.VI.1998 1 O T. \& K. Nupponen leg.; Orenburg distr. Orenburgskij Nat. Pk. 12.-17.VI.2001 3 Ơ J. Kullberg \& M. Zalewski leg.

Distribution. Canary Islands (Klimesch 1990), S. Europe (Parenti 1996), Turkmenistan (Sruoga 1990, as Biselachista spinigera).

Remarks. New to Russia.

\section{Elachista (Elachista) utonella Frey, 1856}

Verbljushka 14.VII.1998 1 O’ K. Nupponen leg.; Kuvandyk 20.VII.1998 1 O K. Nupponen leg.; Ajat River 4.VII.1997 1 \& K. Nupponen \& J. Junnilainen leg.; Arkaim 9.VII.1997 1 ơ K. Nupponen \& J. Junnilainen leg.; Berlin 30.VI.-1.VII.1997 1 O’ 1 O K. Nupponen \& J. Junnilainen leg. 999).

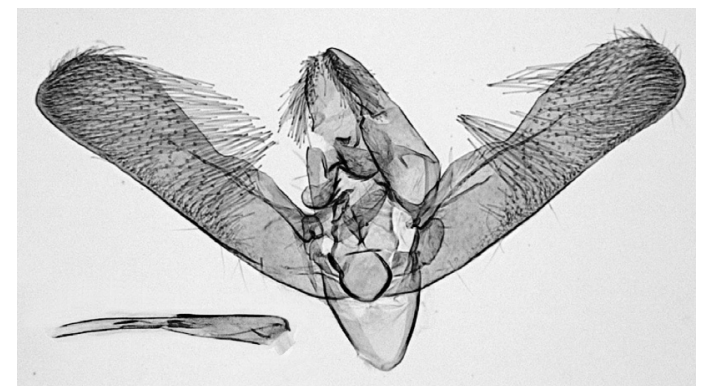

Fig. 38. Elachista devexella sp. n. o' genitalia (holotype, L. Kaila prep. n. 3143).

Elachista (Elachista) devexella Kaila sp. n. (Figs. 37-40)

Holotype 0': Russia, S. Ural, Orenburg distr.

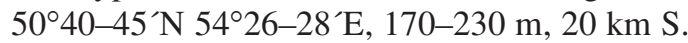
Pokrovka village, Schibendy valley 7.VI.1998 T. \& K. Nupponen leg., L. Kaila prep. n. 3143 (in coll. Nupponen).

Diagnosis. Elachista devexella belongs to the E. tetragonella group as delimited by Kaila (1999a). Its bilobed mesial knob of gnathos and the very short uncus lobes indicate a close relationship with E. trapeziella Stainton, E. kebneella Traugott-Olsen \& Nielsen, E. cinereopunctella (Haworth) and E. imatrella Schantz. From all these species it is readily separated by the peculiar shape of the valva with an expanded and distally oblique cucullus.

Description. Wing span $7.3 \mathrm{~mm}$. Length of labial palpus equal to diameter of head, ochreous grey above, mottled by darker grey scales below. Head, neck tuft, scape of antenna, tegula and thorax ochreous grey, tip of tegula and mesothorax paler grey. Flagellum of antenna grey. Foreleg leaden grey, mid- and hindleg paler. Forewing ground colour grey, mottled with brownish tips of scales; in the middle of wing at fold small somewhat darker brown spot which is inwardly and outwardly narrowly bound by white. Fringe scales concolorous with ground colour. Hindwing and underside of both wings grey with concolorous fringe scales.

Male genitalia: Uncus lobes very short, broad and rounded, mesially hardly separated from each other, ventrally densely covered by thick scales. Mesial knob of gnathos divided into two elongate lobes. Median plate of juxta rounded, concave. Juxta lobes laterally somewhat produced, a little 


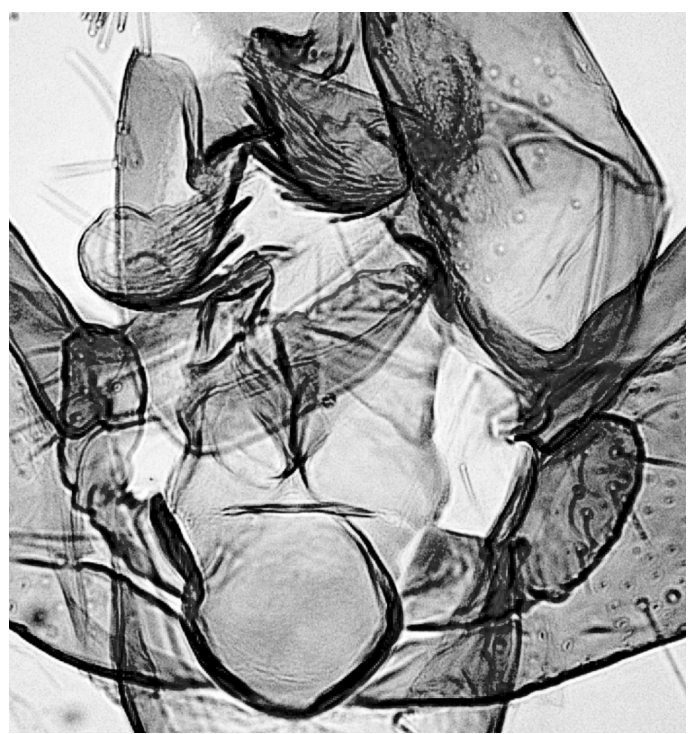

Fig. 39. Elachista devexella sp. n. gnathos, juxta and digitate process (holotype, L. Kaila prep. n. 3143).

longer than wide, median margin slightly truncate joining distal margin at an obtuse angle, distal margin almost straight, with a few setae, lateral margin straight. Digitate process medially angled, club-shaped, 1/5 length of valva. Basal and distal fold of costa of valva meet at $1 / 4$ length of valva, costa somewhat convex; sacculus straight joining cucullus without an angle. Cucullus expanded, size half of the total of valva, distally somewhat oblique. Vinculum large, rounded, without saccus. Aedeagus straight, 2/3 length of valva, basally broadest, with minute caecum, vesica with weakly sclerotised cylindrical cornutus, length of which about $1 / 6$ length of aedeagus.

\section{Elachista (Elachista) alpinella Stainton, 1854}

Iremel, 1300-1500 m, 11.VII.1997 1 O’ K. Nupponen \& J. Junnilainen leg.

Distribution. Holarctic (Kaila 1999b).

\section{Elachista (Elachista) sp. nr. kilmunella}

Russia, S. Ural, Cheliabinsk distr. 52 $39^{\prime} \mathrm{N}$ 59³4’E, 350 m, Arkaim res. nr. Amurskii vill. 14.VI.1996 1 O’ K. Nupponen, J.-P. Kaitila, J. Junnilainen \& M. Ahola leg.

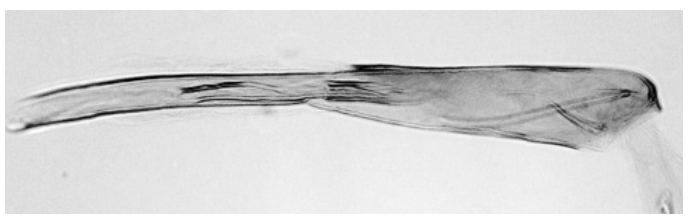

Fig. 40. Elachista devexella sp. n. aedeagus (holotype, L. Kaila prep. n. 3143).

Remarks. The single specimen was collected from steppe. Its genitalia differ from the Eriophorum feeding E. kilmunella Stainton by the broad valva and stout cornuti. It may represent an undescribed species, but the material available is too limited for a safe identification.

\section{Elachista (Elachista) albifrontella (Hübner, 1817)}

Suleimanovo 14.VI.2001 1 O' K. Nupponen leg.; Miass 26.VI.1997 1 O' K. Nupponen \& J. Junnilainen leg.

Distribution. Europe, Siberia (Kaila 1992).

\section{Elachista (Elachista) apicipunctella Stainton, 1849}

Iremel, 900-1300 m, 23.VI.19962 O K. Nupponen, J.-P. Kaitila, J. Junnilainen \& M. Ahola leg.

Distribution. Europe.

\section{Elachista (Elachista) sp.}

Russia, S. Ural, Cheliabinsk distr. $55^{\circ} 01^{\prime} \mathrm{N} 60^{\circ} 06^{\prime} \mathrm{E}$, 350 m, Miass, Ilmen State Res. 26.VI.1997 1 O' K. Nupponen \& J. Junnilainen leg.

Remarks. The species, represented by a single specimen only, is a member of the notoriously difficult Elachista bifasciella group. It is not attributable to any species known to us, but the material available does not enable us to judge its status further.

\section{Elachista (Elachista) diederichsiella Hering, 1889}

Iremel, 900-1300 m, 25.-26.VI.1996 2 0’ K. Nupponen, K.-P. Kaitila, J. Junnilainen \& M. Ahola leg.

Distribution. Europe, Siberia (Kaila 1992). 


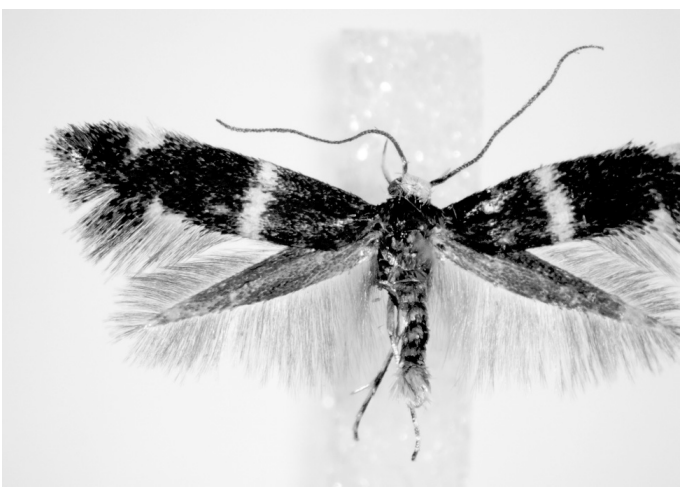

Fig. 41. Elachista baikalica Kaila ơ' (Miass).

Elachista (Elachista) baikalica Kaila, 1992 (Figs. 41 and 42)

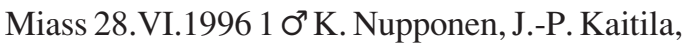
J. Junnilainen \& M. Ahola leg., 28.VI.1997 6 07 K. Nupponen \& J. Junnilainen leg., 19.VI.1998 1 $\mathrm{O}^{7} \mathrm{~J}$. Junnilainen leg.; $20 \mathrm{~km} \mathrm{NW}$ Miass

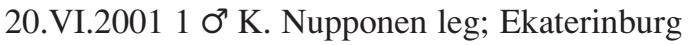
27.VI.2001 2 O’ K. Nupponen leg.

Distribution. Previously known from Siberia: Irkutsk area and Altai Mts. (Kaila 1992). Specimens reported as E. luticomella Zeller from Russian Far East by Sruoga (1995) have been re-examined by L. Kaila and are also referable to $E$. baikalica Kaila. The identification of these species is explained by Kaila (1992).

Remarks. New to Europe.

\section{Elachista (Elachista) herrichii Frey, 1859}

Arkaim 22.VII.1998 1 ( $\sigma^{7}$ K. Nupponen leg.; Kidriasovo 28.V.1998 1 O'T. \& K. Nupponen leg.

Distribution. Europe. In addition, there is one specimen of E. herrichii collected from Russia: Tuva Rep.: E. Tannu-Ola Mts., Khol-Oozha 1998 J. Jalava \& J. Kullberg leg. (ZMH).

\section{Elachista (Elachista) anserinella Zeller, 1839}

Miass 13.VI.1996 $10^{7}$ K. Nupponen, J.-P. Kaitila, J. Junnilainen \& M. Ahola leg.; 29.V.2001 1 O’ K. Nupponen leg.

Distribution. Europe, Siberia (Kaila 1992).

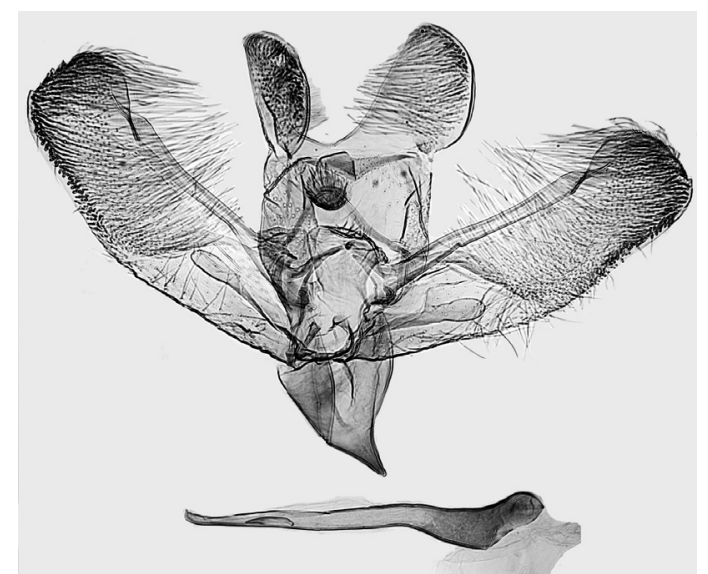

Fig. 42. Elachista baikalica Kaila ơ genitalia (Miass, L. Kaila prep. n. 3117).

\section{Elachista (Elachista) maculicerusella Bruand, 1859}

Elachista cerusella (Hübner, 1796)

Elachista monosemiella Rössler, 1881

Kuvandyk 14.VI.1998 1 O’T. \& K. Nupponen leg. Distribution. Europe, Siberia, C. Asia (Kaila 1992).

Acknowledgements. We thank the following persons for guide services, assistance, company or other kind of help during the expeditions: Mr. Matti Ahola (Reisjärvi, Finland), Mr. Pavel Gorbunov (Ekaterinburg, Russia), Mr. Sergey Kornev (Orenburg, Russia), Mr. Leonid Korshikov (Orenburg, Russia), Dr. Pavel Kulikov (Ekaterinburg, Russia), Dr. Alexander Lagunov (Miass, Russia), Mr. Alexander Malozemov (Ekaterinburg, Russia), Mr. Yuri Mikhailov (Novouralsk, Russia), Mrs. Elena Nupponen (Espoo, Finland), Mr. Boris Roldugin (Ekaterinburg, Russia). We are also grateful to the Lepidopterological Society of Finland for a partial grant to three expeditions. Dr. V. Sruoga and Mr. I. Sulcs gave valuable comments on the manuscript which are greatly acknowledged.

\section{References}

Albrecht, A. \& Kaila, L. 1997: Variation of wing venation in Elachistidae (Lepidoptera: Gelechioidea): methodology and implications to systematics. - Systematic Entomology 22: 185-198.

Eversmann, E. 1844: Fauna lepidopterologica VolgoUralensis. Casani.

Falkovich, M. I. 1986: [Lepidoptera of Kuldzhuktau mountains and adjacent plateau] — Fauna Lepidoptera USSR. Trudy Vses. Entomol. Obshch. 67: 131-186. [In Russian]. 
Falkovich, M. I. 1990: Chapter 35. Family Elachistidae. In Keys to the insects of the European part of the USSR, ed. G. S. Medvedev, Vol. IV, part II, E. J. Brill. Leiden, New York, Köbenhavn, Köln, pp. 628-687.

Kaila, L. 1992: The Elachistidae of southern Siberia and Central Asia, with descriptions of five new species (Lepidoptera). — Entomologica Fennica 3: 177-194.

Kaila, L. 1995: A revision of the North American Perittia (=Onceroptila), with first Nearctic records of the genus Mendesia (Elachistidae). - Journal of the Lepidopterists' Society 49: 208-222.

Kaila, L. 1996: A revision of the Nearctic Elachista s. 1. I. The tetragonella group (Lepidoptera, Elachistidae). Entomologica Scandinavica 27: 217-238.

Kaila, L. 1997: A revision of the Nearctic species of Elachista s. 1. II. The argentella group (Lepidoptera, Elachistidae). — Acta Zoologica Fennica 206: 1-93.

Kaila, L. 1999a: Phylogeny and classification of the Elachistidae s.s. (Lepidoptera: Gelechioidea). — Systematic Entomology 24: 139-169.

Kaila, L. 1999b: A revision of the Nearctic species of the genus Elachista s. l. III. The bifasciella, praelineata, saccharella and freyerella groups (Lepidoptera, Elachistidae). - Acta Zoologica Fennica (Helsinki) 211: 1-235.

Kaila, L. \& Junnilainen, J. 2002: Taxonomy and identification of Elachista cingillella (H.-S.) and its close relatives (Lepidoptera: Elachistidae), with descriptions of two new species. - Entomologica Fennica 13: 167-188.

Klepikov, M. A. 2001: [On the elachistid fauna (Lepidoptera, Elachistidae) of Jaroslavskoy oblast] Sovremennie problemi biologii, khimii, ekologii i ekologicheskovo obrazhovanija (Jaroslav) 2001: 130-132. [In Russian].

Klimesch, J. 1990: Beitraege zur Kenntnis der Microlepidopterenfauna des Kanarischen Archipels. 10. Breitaeg: Elachistidae. — Vieraea 19: 185-192.

Kozlov, M. V. \& Kaila, L. 2001 [2002]: The identity of Tinea megerlella Hübner, [1810] — a long-lasting confusion between Elachista (Elachistidae) and Adela (Adelidae). - Nota lepidopterologica 24: 3-10.

Nielsen, E. S. \&Traugott-Olsen, E. 1987: Four new West Palaearctic species of Elachistidae (Lepidoptera). Entomologist's Gazette 38: 103-113.

Nupponen, K. \& Fibiger, M. 2002: Contribution to the knowledge of the fauna of Bombyces, Sphinges and Noctuidae of the Southern Ural Mountains, with description of a new Dichagyris (Lepidoptera: Lasiocampidae, Endromidae, Saturniidae, Sphingidae, Notodontidae, Noctuidae, Pantheidae, Lymantriidae, Nolidae, Arctiidae). — Phegea 30: 121-185.

Olenev, A. M. 1965: The Urals and Novaja Zemlja. Moscow. [In Russian].

Parenti, U. 1977: Revisione degli Elachistidi (Lepidoptera, Elachistidae) paleartici. IV. Le species di Elachistidi descritte da H. Frey e P. C. Zeller. - Boll. Mus. Zool. Univ. Torino 3: 19-50.

Parenti, U. 1978: Nuove specie paleartiche del Genere Elachista Treitschke (Lepidoptera, Elachistidae). Bollettino del Museo di Zoologia dell'Università di Torino 1978 (4): 15-26.
Parenti, U. 1981: Nuove specie di Elachistidi paleartici (Lepidoptera, Elachistidae). I. — Bollettino del Museo di Zoologia dell'Università di Torino 1981(4): 49-64.

Parenti, U. 1983: Elachistidi del Giappone (Lepidoptera, Elachistidae). - Bollettino del Museo Regionale di Scienze Naturali — Torino 1: 1-20.

Parenti, U. 1992: Elachista adscitella Stainton ed Elachista revinctella Zeller (Lepidoptera, Elachistidae). Bollettino del Museo Regionale di Scienze Naturali Torino 10: 237-244.

Parenti, U. 1996: Elachistidae. In: O. Karsholt \& J. Razowski (eds.), The Lepidoptera of Europe. Apollo Books, Stenstrup. pp. 68-73.

Parenti, U. 2001: The Elachistid moths of the Löbbecke Museum of Düsseldorf (Lepidoptera: Elachistidae). SHILAP Revta. lepid. 29: 249-254.

Parenti, U. 2002: Corrections and additions to the Checklist of European Elachistidae (Lepidoptera: Elachistidae). — SHILAP Revta. lepid. 30: 149-153.

Sachkov, S. A. 1995: new for Europe species of Microlepidoptera (Lepidoptera: Scythrididae, Elachistidae) from Samara region. - Actias 2: 77-78.

Schmidt Nielsen, E. \& Traugott-Olsen, E. 1978: Elachistidae (Lepidoptera) described by O. Staudinger, J. Mann and C. Mendes. - Entomologist's Gazette 29: 5-16.

Sinev, S., Yu \& Sruoga, V., A. 1997: 29. [Sem. Elachistidae — zlakovie moli-mineri]. In: Ler, P. A. (ed), Key to the insects of Russian Far East. Vol. V. Trichoptera and Lepidoptera. Pt. 1. Dal'nauka, Vladivostok. pp. 491502.

Sruoga, V. 1990: Seven new species of Elachistidae (Lepidoptera) from the USSR. - Tijdschrift voor Entomologie 133: 75-84.

Sruoga, V. 1995: Description of Cosmiotes cornutifera sp. $\mathrm{n}$. and a provisional check-list of Elachistidae fauna of Far-Eastern Russia (Lepidoptera, Elachistidae). Phegea 23: 157-162.

Sugisima, K. 1999: A new littoral Elachista species, E. kobomugi sp. nov., and its close relatives (Lepidoptera, Elachistidae) from Japan. — Trans. lepid. Soc. Japan 50: 247-263.

Traugott-Olsen, E. 1988: The Elachista triseriatella Stainton complex, with descriptions of eight new species (Lepidoptera: Elachistidae). — Entomologist's Gazette 39: 293-312.

Traugott-Olsen, E. 1990a: The Elachista dispilella Zellercomplex, with descriptions of ten new species (Lepidoptera, Elachistidae). - Entomologist's Gazette 41: $35-68$.

Traugott-Olsen, E. 1990b: Descriptions of four new species of Elachistidae (Lepidoptera) and diagnoses of Elachista pollutella Duponchel, 1843 and Elachista constitella Frey, 1859. - SHILAP Revta. lepid. 18: 273-285.

Traugott-Olsen, E. 1992: The Elachista dispunctella (Duponchel, 1843) complex with descriptions of new taxa (Lepidoptera, Elachistidae). - SHILAP Revta. lepid. 20: 197-316. 
Traugott-Olsen, E. 1996: Three new Elachista species of the collitella-complex from Italy, France, Austria and Spain. - Entomologist's Record 108: 123-131 + 1 pl. Traugott-Olsen, E. 2000: Variation in Elachista biatomella (Stainton, 1848). A review of the species-group, with description of four new species (Lepidoptera: Elachistidae). - SHILAP Revta. lepid. 28: 63-90.

Traugott-Olsen, E. \& Schmidt Nielsen, E. 1977: The Elachistidae (Lepidoptera) of Fennoscandia and Denmark. Fauna Entomologica Scandinavica 6: 1-299. 